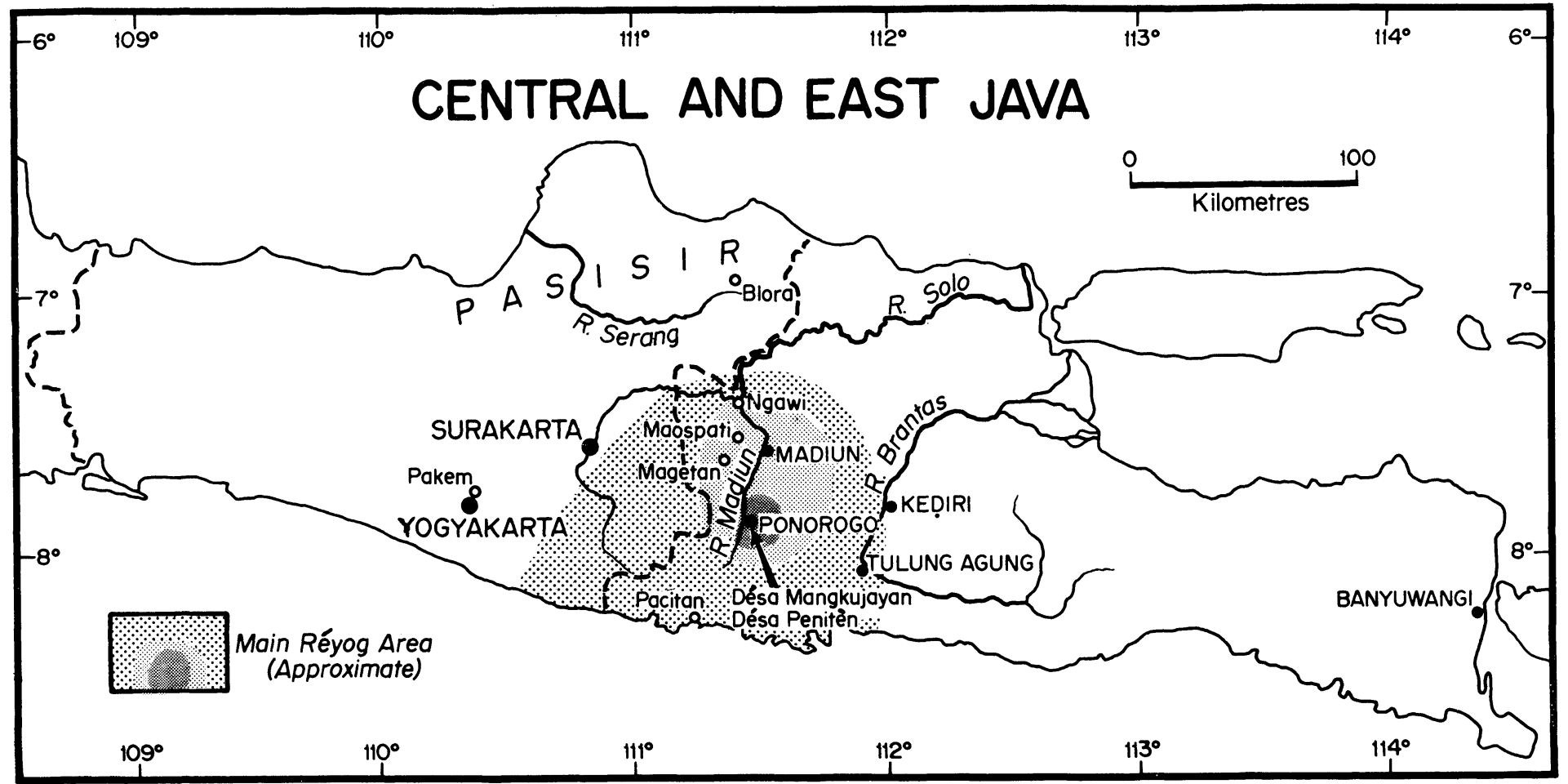

MAP 1



Plate 1: Slomprèt (left) and angklung in a gamelan réyog (Ponorogo). 


\title{
PERFORMANCE, MUSIC AND MEANING OF RÉYOG PONOROGO*
}

\author{
Margaret J. Kartomi
}

After word had spread that a réyog performance was to take place one morning late in 1971, the inhabitants of several villages gathered outdoors around a shaded spot in Desa Mangkujayan (near Ponorogo, East Java), where a small gamezan ensemble was being set up.

The moment the music began, an exhilarating atmosphere was created, the reedy penetrating tone of the shawm (s zomprèt) shifting its melodic figurations over a pulsating pattern of sound created by kettles (kenong), suspended gongs (kempul), a small drum (tipung) and several three-tube, Ponorogo-style, bamboo angkiung decorated in red and white. A very large drum (kendang Ponorogo) worked with the slompret to give an element of continuai musical variety in contrast to the regular rhythm and melody provided by the rest of the ensemble. The musical prologue ended with a curtain of musical silence. ${ }^{1}$

Probably most members of the audience, who had come in anticipation of several hours of entertainment and spectacle, had forgotten, if indeed they had ever been wholly aware of, the full meaning of this art form of ancient origins. Seven dramatic scenes were to be presented by the réyog performers, marked off from one another by silence. No particular plot would be enacted. But the masked and unmasked characters about to appear were well known to the audience through many previous performances and through the associated reyog legend, the various forms of which are known collectively today as the "Babad Kediri" or "Babad Réyog Ponorogo." Moreover, a certain continuity of dramatic content would be apparent throughout, especially in the climactic sixth scene, in which the great pageant figure Barong would appear.

Despite the largely secularized and depoliticized nature of the performance the audience expected to witness, they had already begun

*I have spelled some of the Javanese names of dances and musical pieces in their modern Indonesian form in accord with the way in which these names were passed on to me during my recent visits to Ponorogo.

${ }^{1}$ Musical form is determined by both silence and sound. This is especially striking in the case of a réyog performance, where musical pieces which together form a dramatic unity are clearly delineated from each other by silence. This is quite different from the almost unbroken musical continuity of an all-night wayang (puppet theater) performance.

The importance of silence in réyog brings to mind an essay by Gisèle Brelet, "Music and Silence," in Susanne Langer's Reflections on Art (Baltimore: Johns Hopkins Press, 1958), pp. 103-121. Brelet writes: "If the musical work falls back now and again into silence, to be reborn from it, those silences are not scattered bits of nothingness in the duration of the music.. . ; rather they are of one substance with the music. . . Becoming and movement, too, arise from silence" (pp. 105 and 107). 
to respond to the occasion with steadily increasing excitement, aware of the undertones of mysticism, sexuality, humor, and politics still inherent in the present-day concept of reyog Ponorogo. The role of the audience was not on1y to watch but also to contribute to the occasion by emitting blood-curdling yells, sardonic ululations, humorous comments, and the like. The men in the audience were also ready to participate in long passages of dor (rhythmic chanting), helping to engender and maintain an atmosphere of high emotional excitement.

After a short introduction on the kendang and slompret, the whole ensemble entered to play the opening piece ("Pambuka"). Two handsome boys aged twelve and sixteen emerged. Each rode a plaited bamboo hobby-horse painted in combinations of black, red, and yellow on a white background. These colors have long had magical significance in Java. ${ }^{2}$ The elegantly designed hobby-horses had deeply bowed heads, open mouths, and an upward gaze. ${ }^{3}$ Unlike in most other Javanese dances, the boys' dancing did not begin with respectful bowing movements (sembah).

The dancers' clothes resembled the costumes of satria (knights) in the commercial ketoprak or wayang wong theater, except that modern long-sleeved cotton shirts covered their bare chests, and they wore bejewelled, braided, blue batik head-scarves instead of elaborate leather headdresses. Like the satria in wayang wong, each dancer had two long tasseled, red-and-yellow sampur (dance-scarves) attached to his buckled belt, so that they hung over his knee-length trousers of black velvet trimmed with gold braid. The costumes were decorated with a glittering sash (srémpang) worn across the chest, a necklace (kancéh), long ear ornaments (sumping) and braided wristbands (gelang tangan), with a keris attached aslant at the back. A piece of bațik hung from each dancer's belt, with rough folds in front." Like some male kețoprak dancers, the dancers' sideburns were extended toward each cheekbone with black makeup in "turi bud" (ngudup turi) shape. Their lips were colored the dark red shade of the inner skin of mangosteens (manggis karengat). Their eyebrows were thin pencil-line arcs, drawn above each eye and ending high on the forehead in feminine, "new moon" (tanggal sepisan) style. The masculine makeup sign $\wedge$ was drawn between their eyebrows.5 Just below each dancer's elaborate belt (important in the reyog legend, according to which King Klana Sewandana gave magic belts to his knights to help them win victory over the Alas Roban

${ }^{2}$ These colors "are associated in Java as well as in Bali among other things with the four cardinal points." Claire Holt, Art in Indonesia (Ithaca: Cornell University Press, 1967), p. 104. According to Sutardjo Kartohadikusumo, black is a symbol of negative emotions such as fear, shyness, jealousy, longing and loss; red symbolizes anger and concealed selfish impulse; yellow symbolizes male-female relations, desire, luck and praise; and white symbolizes cleanliness, clarity, and purity. See his Désa (Yogyakarta: Sumur Bandung, 1965), p. 96.

${ }^{3}$ Javanese hobby-horses occur in a variety of designs, sometimes in a natural bamboo color, at other times in various combinations of black, red, yellow, and/or white, with occasional use of pale blue.

${ }^{4}$ It may also be worn Panji style $(W)$, according to the Javanese performing
Poedijono. artist Poedijono.

${ }^{5}$ The common feminine makeup sign is ! drawn between the eyebrows. 


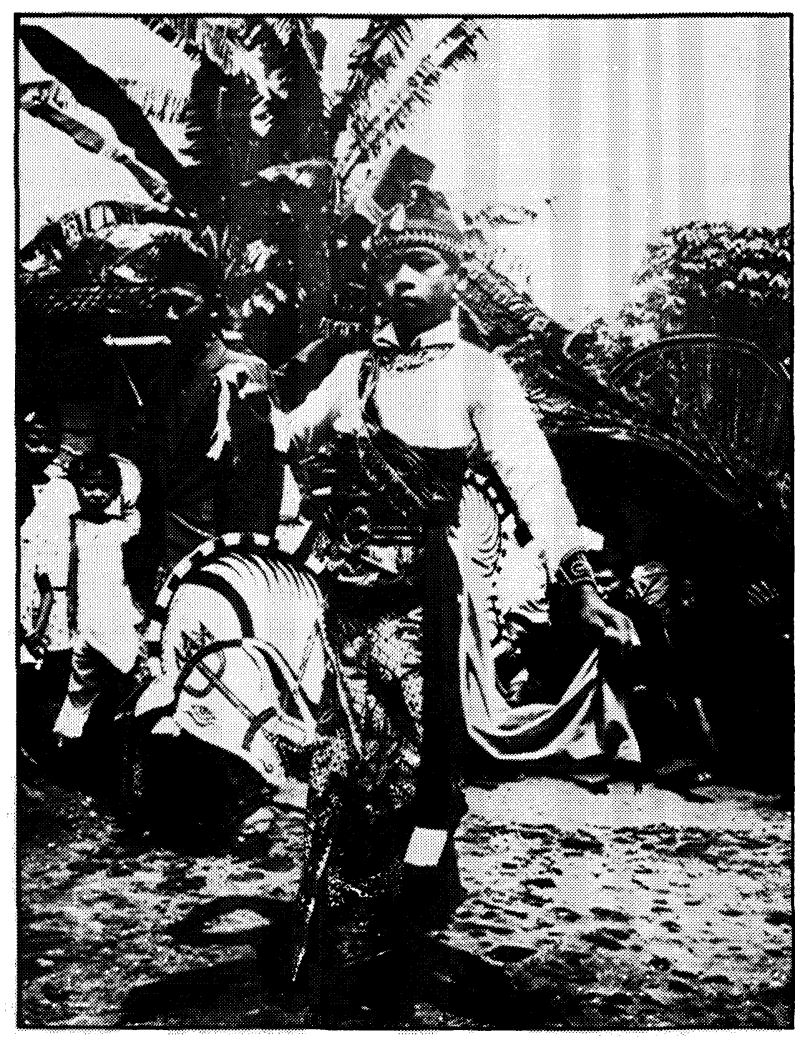

Plate 2: A jaran képang dancer (Ponorogo).

army--see below), a cylindrical piece of wood was attached with string to hold each hobby-horse in place, and thus allow the dancer complete freedom of movement with both hands. ${ }^{6}$

Members of the audience knew that some of these dancers might be dressed as transvestites (gemblak). These would be boys wearing com-bined feminine and masculine or purely feminine clothes, such as a blouse (kebaya), a wrap-around skirt (jarik batik), and a scarf (sampur or sléndang) worn around the neck in feminine style, either hanging loosely or arranged diagonally across the breast and tied on the hip. ${ }^{7}$

${ }^{6}$ Hobby-horse dancers in most areas of Java hold their horses with their left hand, which naturally precludes left-hand dance movements. Where the hobby-horses are attached to the dancers' costumes, as is normal in Ponorogo, the potential quality and variety of hand movements are, of course, increased.

7Th. Pigeaud's Javaanse Volksvertoningen (Batavia: Volkslectuur, 1938, plates 75 and 90), pp. 224 and 300 , shows a pair of gemblak in a réyog Ponorogo performance held several decades ago. Plate 90 shows two gemblak, each wearing a feminine bun hairdo, earrings (suweng), a kebaya, and a sléndong hanging to mid-calf length. But one gemblak wears a combination of masculine and feminine clothes, substituting a pair of knee-length trousers for the jarik batik worn by the other, totally femininelooking gemblak. Both ride hobby-horses attached to their costumes. The horses are painted mostly in white, with bowed heads and an upward gaze, similar to that pictured in Plate 2. In plate 75 , the two gemblak stand near the gamelan, facing a beckoning, long-nosed Pujangganom, similar in appearance to a present-day Pujangganom. He is dancing in front of a Barong which is considerably smaller than the Barong pictured below in Plate 3 . 
Today, as in this performance, the boys often wear wayang wong dress replete with trousers, for convenience when riding the hobby-horses. Even though these are knightly costumes, they are seen as appropriate to the gemblak tradition because they are regarded as the costumes of female warriors of the Srikandi type. Thus they combine feminine and masculine characteristics.8

With modest, downcast eyes, jaran képang (hobby-horse) dancers performed sampak biyasa (ordinary fast dance) based on two types of movement, one performed while standing on one spot (jinem) and the other in fast, galloping motion (srisig). Beginning with the srisig, one dancer circles behind the other, horse-bells and akle-bells ringing, with both elbows outstretched and arms curving inwards. Both dancers performed simple dance figures in the air with their hands and fingers, betraying a certain lack of control, variety and finesse (in comparison with the complex and exceedingly refined hand movements [ukel] of the well-trained Javanese dancers of, say, the best professional wayang wong troupes). Sometimes they picked up both ends of their dance scarves (see plate 6), which they twisted rhythmically and flicked across their hands, and then threw behind them. Coming to a halt, they performed slightly more elaborate movements of self-adornment, including one normally reserved for female dance roles on $1 y--t h e$ trap jamang, a distinctive gesture of arranging feminine headdress hair-locks.

The jaran képang dancers then resumed their circular formation, riding their horses with serious concentration, while the noisy audience called out amusing, sardonic remarks. After a while, they burst into a fast interlocking dor in regular rhythm and varied pitch, chanting meaningless syllables. Members of the audience knew that in the past, including the general elections of 1971 , a variety of political catchwords and slogans had been chanted in dọ during réyog performances organized by political groups and parties, unlike the nonsense syllables chanted in this largely depoliticized performance. Whatever the content, however, the dor always serves to intensify the excitement of the occasion.

The boys danced with impassive and downcast faces, absorbed by their roles and the mesmerizing element of the music, appearing to be unaware of the electric mood of the audience. The drummer, who had been playing what seemed to be an ever-changing sequence of timbres and rhythms, gave a loud rhythmic signal for the ensemble to slow down (to perform a suwuk) and for the dancers to exit, which they did before the last kempul stroke. The musical tension was then quickly released by a short, subdued, rhapsodic, free-meter epilogue on slompret and kendang. The instruments were silent.

The next episode began with a virtuoso buka on the kendang, and the clamorous atmosphere was restored as the wild, screaming slompret began to play a piece called "Ponoragan." Another pair of solemn-faced jaran képang dancers entered to perform a sampak ombyok (tassel sampak), one wearing a roughly wrapped jarik bațik and the other a pair of ve1vet trousers, as in the first dance. They trotted at a fair pace

${ }^{8}$ In fact, the boys wear a variety of costumes in different réyog performances today. The costumes seem to be in a continual state of change, depending partly on the finances and theatrical connections of a particular group. 
around the ring, swaying their horses from side to side, the audience participating in the rhythmic pulsation with interlocking dor.

Quite frequently, after a rigorous bout of drumming, the music changed tempo as a reflection of the increased level of excitement. Now fast, now slow, now at a quickening tempo, "Ponoragan" culminated in a dor passage performed at breathtaking speed, not dissimilar to the virtuoso cak sections of a Balinese kecak performance. The dor lasted throughout the piece until the final explosive burst of drumming, which led to a relatively long suwukan, a slightly delayed final kempul stroke and, as usual, a free-metric postlude on the slomprèt and kenḍang, followed by silence.

Musically, this second scene had been highly exciting. Dramatically, not much had happened "on stage," but the music had built up such a high level of tension through the compelling metric drive, the feverishly fast interlocking dor and its constantly high level of dynamics, that the tension took longer than before to be released, and thus the intensity of the music took longer to reduce through the suwukan and epilogue. From now on the music was to become structurally simpler, as the syncopated kempul part of the first two pieces (fairly rare in gamelan music as a whole) assumed a straightforward, rhythmically regular punctuation pattern throughout the rest of the performance.

After a quick buildup of instrumental forces in the buka, the gending "Sontoloyo" began at a fast pace, with dor superimposed on the gending. Not until the kendang had given an intensive long braking signal and the tempo of the ensemble had considerably slowed down did the next dancers enter: the clown figures Potrojoyo and T1edek Bisu ("mute teaser").10 Wearing comic masks (topèng dagezan), thè walked around the ring with springing steps, performing comic movements ( lezucon). The silly-looking Tledek continually bumped into the more substantial Potrojoyo, each time causing the audience to laugh. The clowns performed stock Javanese dance movements in awkward fashion, making a parody of serious dance expressions. They made their exit before the postlude.

The buka of the next piece, "Jaran Képang," featured the slomprèt and kendang, after which the first pair of jaran kepang dancers returned to dance a sampak, accompanied this time by fast regular-rhythmic clapping, dor, and exceedingly loud, virtuoso drumming. The audience

${ }^{9}$ Gending, in general parlance, means any gamelan piece. In the strict theoretical sense, however, it means a genre of serious pieces in which kempul play no part.

$1^{10} \mathrm{~A}$ character called Potrodjojo is mentioned in W. Staugaard's "Koeda-Képang" (Handelingen van het Eerste Congres voor de Taal-, Land-en Volkenkunde van Java [Weltevreden: Albrecht, 1921], p. 422), as having danced the sexually stimulating tandak in "indecent" fashion with a lady walled Wajang Djepré, arousing the laughter of young and old. This suggests that Potrojoyo may not traditionally have been an innocent clown, as he seemed in the present performance, but that he possibly played an overt sexual part. Perhaps he was really a strong, magically powerful man of the type called warok, dancing suggestively with his young, handsome gemblak. Moreover, the name of the other clown--Tlèdèk-Bisu--is a reminder of the female dancers ( $t$ lèdèk) who perform for hire with street musicians from door to door. Tlèdèk are often prostitutes and sometimes transvestites. 
admiringly and mockingly addressed their calls (senggakan) to the two handsome boys. Such senggakan as Wah!.... la la la la la! would sound sardonic, approving and suggestive to people from a variety of linguistic traditions.

Now the drums slowed their pace, forcing the audience's clapping to follow suit--to fit the anticipated entry of another pair of clowns. The slow clapping emphasized the side-to-side swaying of the hobbyhorses, as the dancers circled the ring several times.

As soon as the clowns entered, wearing striped jackets (surjan), wide belts and black three-quarter length trousers, the audience began to mock them. They were the small, lithe Gembyong and the big, slowmoving, dense-looking Tutul. The audience began throwing pieces of grave1 at Tutu1, but he proved too big and easy a target. So they turned their attention to little Gembyong, who kept somersaulting nimbly away from the approaching missiles, and then suddenly impressed everyone with a whimsical display of "the splits," headstands, and handstands.

In the next scene, the music became yet faster, more virtuoso, and more feverish. Entitled "Pujangganom Nylamur Dadi Pențul" (Pujangganom impersonating the clown Pentul), it began with a buka in an irregular rhythm on the drum, followed by a loud, high-pitched slompret entry, with outrageously wide leaps (of a ninth, for example) from high longheld tones to low ones. A sudden blood-curdling yell--"Ya! . . ."-from the audience electrified the atmosphere early in the piece. A regularrhythmic period of dor--ho! ho! ho! ho!--soon broke up, only to return later in irregular-rhythmic form, such as ha! $\boldsymbol{P}_{\mathrm{e} !}<\mathrm{I}_{\text {ha! }}<\underset{\text { ha! }}{\boldsymbol{P} !}$.

A vivid, dramatic entry was then made by Pujangganom (who was, according to the legend, a dwarf). He wore a bright red mask symbolizing his intrepid, rather kasar (rough, crude) character (see Plate 4 below). The mask had white corneas and teeth, deep-sunken eye sockets and 1 arge, semicircular eyes ${ }^{11}$ which looked upwards. Below the high cheekbones were a cheeky, upturned nose and a sma11, receding chin. The prominent teeth emphasized his crudity.12 The long, straight hair was unkempt and straggly, unlike the wide horizontal moustache, which had a gentle wave in it.

A pair of jaran képang boys entered and continued to perform the same srisig dance movements as before, concentrating on their riding, with the same strange, aloof expression on their faces. Pujangganom performed awkward dance movements which were taken as comic antics, causing laughter among the onlookers. As a clown, he mocked and teased the serious hobby-horse dancers, sometimes provoking them and then retreating in an impressively gymnastic way. ${ }^{13}$

\footnotetext{
"Somewhat like the circular eyes of the clowns Bagong and Garèng in wayang kulit (shadow-puppet theater).

${ }^{12}$ Alus (refined) Javanese prefer not to show their teeth when possible.

${ }^{13}$ In a letter, B. R. O'G. Anderson writes that in the 1963-64 period he saw a Pujangganom figure in a PKI (Partai Kommunis Indonesia)-village réyog performance
} 
The sixth piece, entitled "Barongan," accompanied the stately, climactic entry of the great pageant-figure Barong, baited by the clowns Tutul and Genbyong. The music now reached a peak of feverishness. İts regularly pulsating kenong and angklung tones, along with the periodic kempul strokes and the brilliant dor, were mesmerizing in their repetitiveness, while the slompret, the wild crowd noises, and the drumming created a variable musical texture to counter the rigidly regular accompaniment.

This réyog klizing scene, which in modern Indonesian is entitled the tari réyog kelizing (réyog dance parade), was the dramatic highlight of the whole show. The Barong, that famous mythical animal of Javanese and Balinese tradition, wore a spectacular soaring headdress (see Plate 3) of a style unique to Ponorogo. An enormous construction, it centered around a magnificent, life-size tiger head with exaggerated fangs arranged in a fierce-looking pattern of large molars and small incisors. The tiger head was topped with hundreds of peacock feathers, fastened one above the other on a large bamboo frame, with the name of the village owning it proudly printed above the tiger head. The whole construction was held up by the teeth of the performer, biting a bar fixed to the inside of the tiger mask. The blue-green mass of feathers shone brilliantly in the sunlight as it swayed about in graceful waves, high above the heads of the crowd.

The whole gamut of réyog characters are supposed to appear, or reappear, in the réyog kliling scene. Normally only one Barong is present. But this performance was more elaborate than most, for soon after the Barong Désa Mangkujayan entered, a second, slightly smaller Barong appeared. In a free village art form like this, there was apparently no reason why the occasion should not be further glamorized by the stately entry of an extra Barong. The performers of the Barong, the ones to the rear under sackcloth, moved ponderously around, halting to face each of the four arcs of the audience-circle in turn, so that everyone could admire a full view. Occasionally, they scratched their faces with their hands, to the amusement of the crowd, who pressed in on the Barong and had to be pushed back by one of the angklung players.

As if this parade had not been impressive enough, a yet grander entry was then made by the Barong's chief foe in the legend: a masked dancer portraying King Klana Séwandana, to whom the main Barong bowed in subservience. Klana Sewandana was dressed in wayang wong costume, with two glittering srémpang crossing each other on his breast. He held a small stick in one hand, decorated with four red and white paper rosettes.

The king's mask was more finely featured and less fleshy-looking than Pujangganom's (see Plate 5). But that was only to be expected, since the dwarf in the legend was less powerful than the king. Klana's eyes, though less elegant and elongated than the eyes of an alus Javanese leather puppet, were almond-shaped and fairly noble. The nose was relatively long and came to a fine point. Under a wispy moustache his teeth showed, emphasizing the fact that his is a somewhat coarse

flirting outrageously with the jaran képang dancers (who responded with subdued coquetry), at one point even using the long red nose of his mask in an unmistakably obscene way. This aroused some rather tense laughter in the crowd. 




Plate 3: Barong Ponorogo. 


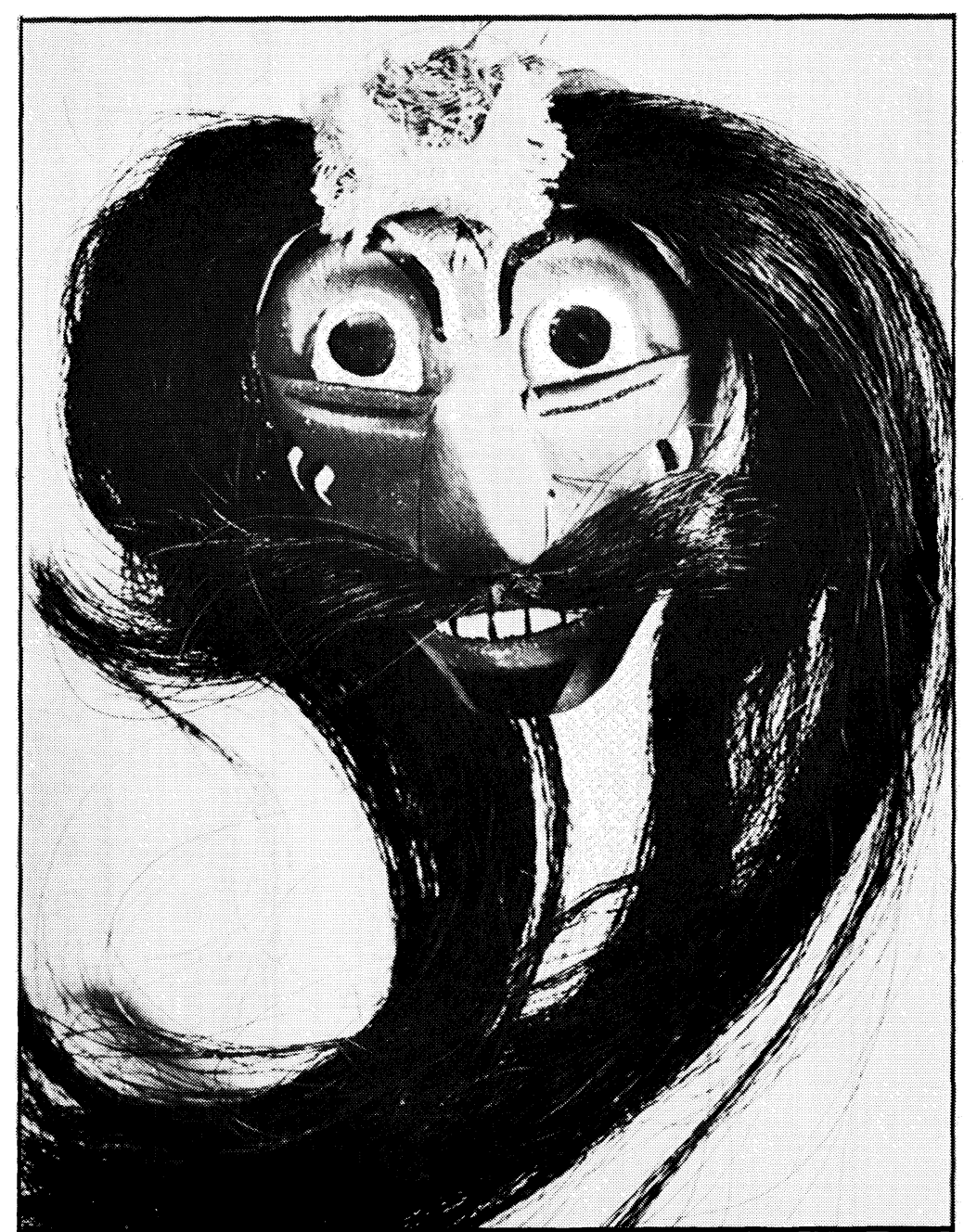

Plate 4: Pugangganom (Ponorogo).

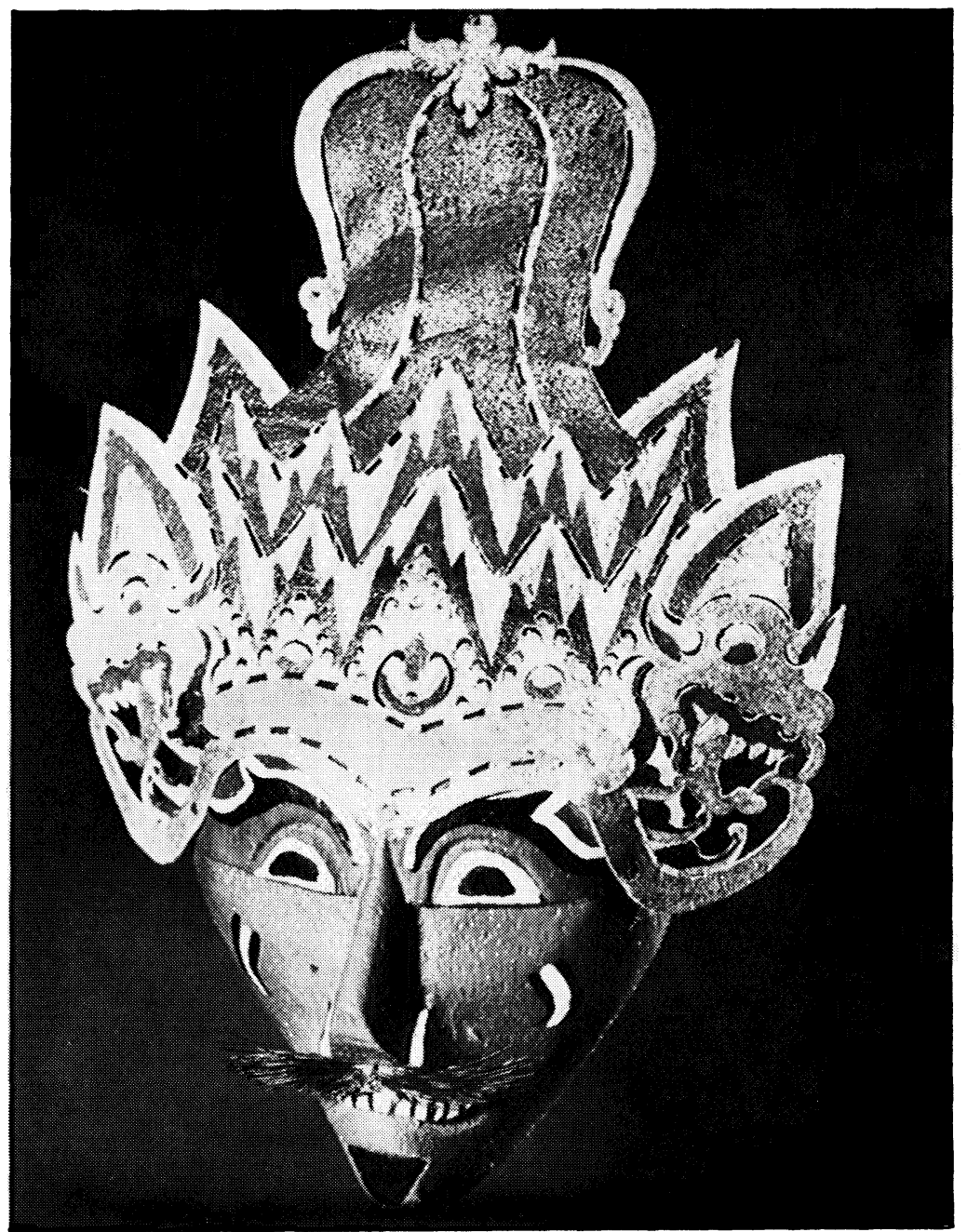

Plate 5: Klana Séwandana (Ponorogo). 
(dugangan) dance role. The red-colored face and direct forward gaze showed the king's power, his strength, and his fierce, courageous mood in times of conflict, such as in the impending battle with the Barong. The multicolored, coarsely chiseled leather crown emphasized his kingly status. The shape of the crown roughly resembled that of the Barong mask which, in turn, was reminiscent of the kayon, the symbol of the universe in wayang kulit.

The main Barong bowed so low to the king, with an awkward, downward sweep of his peacock feathers, that he almost fell over. Meanwhile, Klana Sewandana danced a passive role, as the receiver of the Barong's homage, Klana's occasional movements were abrupt and kasar, with arms jutting out at right angles to his body and hands immodestly placed higher than in the postures normally allowed in the dance of alus characters. With legs slightly bent and wide apart, thus slightly lowering his torso, he held the stick up in his right hand and performed an elegant ukel with his left, the extended hand held at mouth level. In comparison with the main Barong, however, he was restrained and self-controlled, a satria. ${ }^{14}$

The main Barong rose again, kicked out his feet, and shook his head roughly as if trying to regain a sense of balance. He jumped around a little, scratched his mouth with his hand (see plate 6) and performed other animal-like antics. Meanwhile, the two clowns began to tease the two Barong, forcing them to jump up and down, now advancing, now retreating, now assuming a crouched sitting position near the edge of the "stage." When the odds occasionally turned in favor of the two Barong they ponderously chased Gembyong, pouncing forward in widely spaced steps, but usually missing the nimble clown.

After engaging the Barong in mock-fighting dances, one of the jaran képang boys jumped up to sit cheekily on the top of the Barong's tiger head. Although the audience had seen this happen many times before, they gasped again at the athleticism and poise of this twometer jump and the strength of the Barong impersonator's teeth, which could withstand the jolt created by the boy's landing, and could hold up not only a heavy headdress but, in addition, a human being. The Barong performer jerked the jaran képang dancer around as he sat aloft, performing the hand movements of Javanese dance, and periodically waving to the crowd. After a while, the boy leaped down to the ground, immediately resuming his part in the horse parade, in the old introverted manner.

Before the long-awaited Klana-Barong duel began, the second Barong left the scene. The Barong impersonator suddenly lay on the ground in a way that made his great peacock feather crown appear from the front to be standing on the ground without any support whatever. In this way the Barong tried to frighten Klana with a sudden "magic" apparatition.

The contest was in fact between the magic power (kasektén--attained through meditation and self-control) of the king, on the one hand, and the chaotic, chthonic power of the Barong, lord of the underworld, on

${ }^{14}$ There are several Klana characters in Javanese dance, all of whom are said to have come from overseas (sabrang) and are therefore, in some Javanese eyes, rather kasar. Some Klana are more kasar than others. 


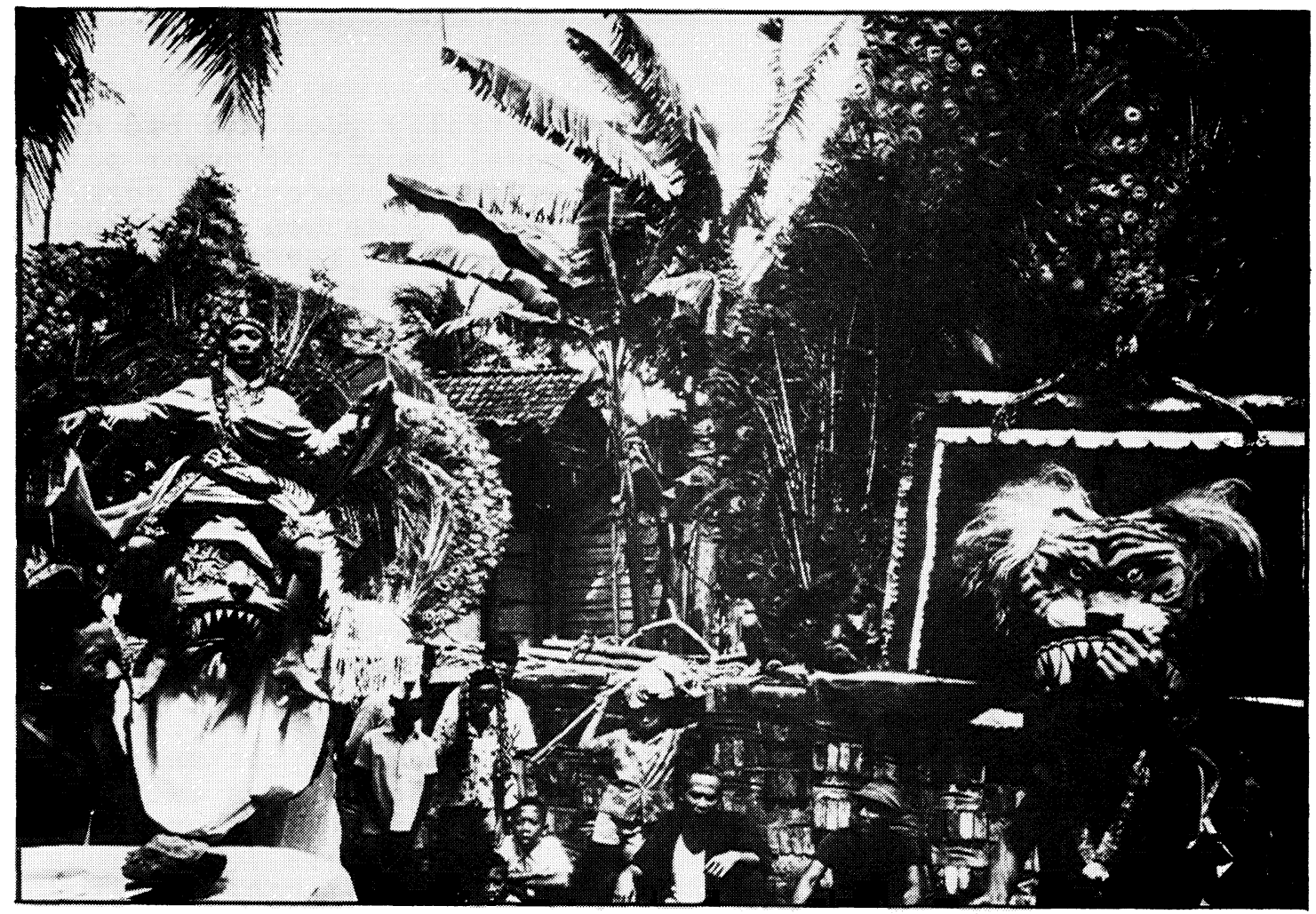

Plate 6: A jaran képang dancer rides a Barong, while a second Barong scratches his mouth (Ponorogo).

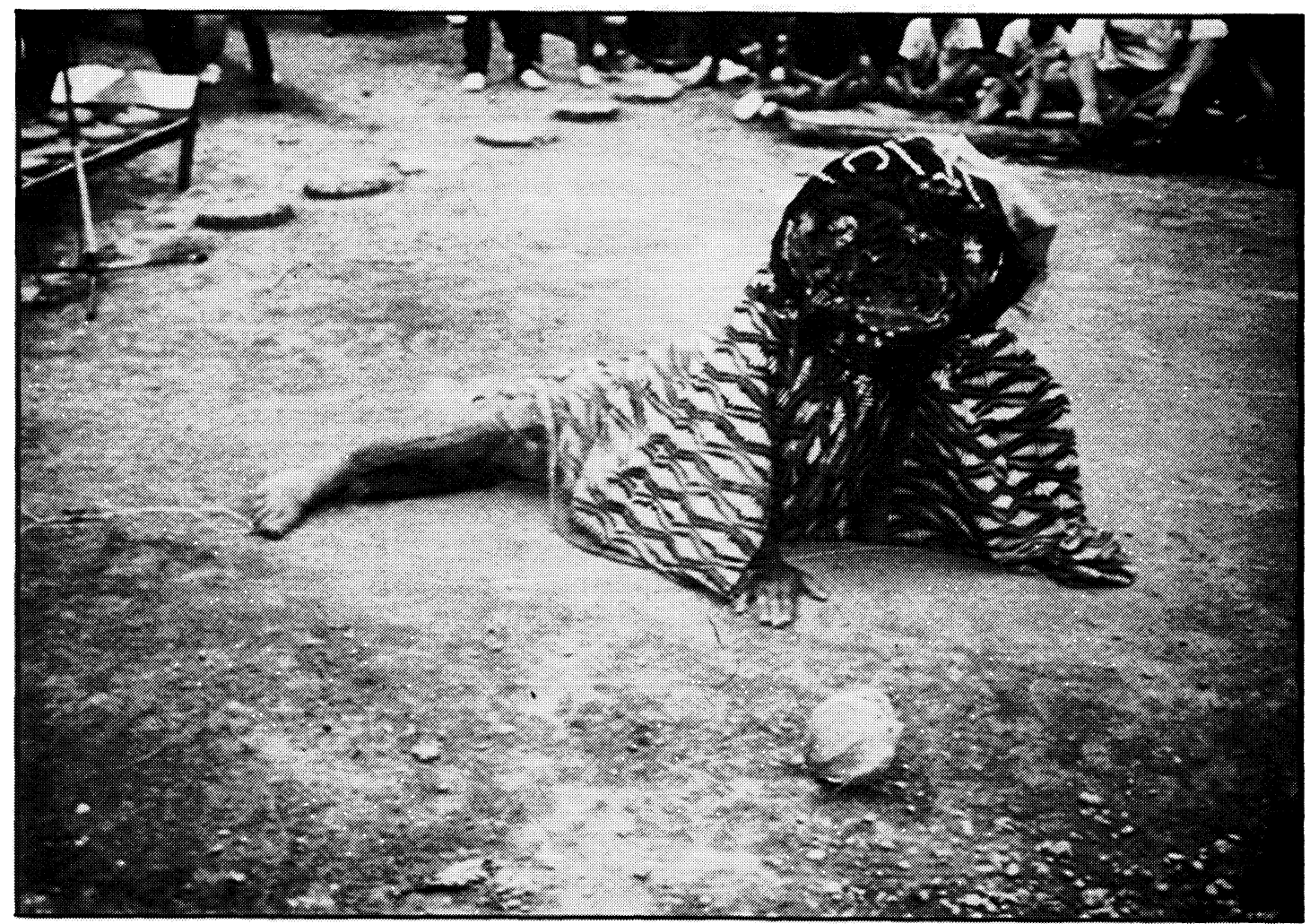

Plate 7: A decrowned Barong in a kucing-kucingan scene (Parit Lapis, Sri Medan, Johore). 
the other. Since both sides possessed potentially good and bad qualities, the crux of the struggle was the unequal amount of power possessed by each side, who together represented a Javanese concept of cosmic dualism. As is usual in such contests, neither side won a permanent, decisive victory. Klana was unable to destroy the eternal Barong, but for the time being he could drastically reduce the Barong's power. Through his own accumulated kasekten, he was able to face the apparition created by the Barong and thus attain, with apparently 1ittle effort, his positive goal of partially defeating the forces of the underworld and reestablishing cosmic order.

The Barong lost the battle (but not the war). Toppling over, he rolled on the ground, the dragging of the enormous headdress emphasizing his defeat and humiliation. His glorious peacock crown--symbol of the power he once had--was removed from his tiger-head mask. Klana then led his "victory" parade, the whole reyog troupe moving after him in circular formation. After making their exit, the gamelan gradually came to a halt. Musical silence followed.

The fina1, seventh scene was the kucing-kucingan (cat-and-mouse) dance. The humiliated, crownless Barong, referred to as a cat, was now to bè set in conflict with Klana Sêwandana's man, Pujangganom. The simple cat-like tiger could now no longer appear in his former role of a splendid, majestic figure. In ensuing contests, he had to rely on his own skill and agility rather than on his magic power, although presumarly he could accumulate this again in the future. His power had temporarily been reduced to that of an ordinary tiger or, in the victorious eyes of Klana's side, of the tiger's less powerful relative-the cat.

A tightrope was set up. After the angklung had started the buka and the fast regular-metric gending "Kucing-kucingan" has attracted the busy participation of kenong and for, the slompret followed the agile movements of the "cat," occasionally hesitating as if to increase the suspense of the daring tight-rope display in the ring. The "mouse" (Pujangganom) writhed along the rope, two meters above the ground, in an attempt to keep free of the approaching "cat." Hanging in a daring stance over the edge of the tight-rope pole, he watched the "cat's" face for a sign of his intentions. The "cat" bounded towards the "mouse" beneath the rope, unable to stop as he raced into the audience, who pushed each other backwards in fright at the sudden confrontation. Eventually the poor "cat" gave up in exhaustion and despair at the superior agility of his opponent, and went to find a drink. Returning with a bottle of water, he mounted the tightrope and poured the water down his throat in a quite unself-conscious manner, his head thrust back in order to get a free flow down his throat. ${ }^{15}$ The two animals then played together, performing daring acrobatic feats. They played hide and seek around the legs of an upturned table. Someone in the audience threw a coconut into the ring which the "cat" pawed and tried several times, unsuccessfully, to pick up. People teased him by

${ }^{15}$ Dancers in trance performances throughout Java (especially in the widespread, ordinary form of jaran képang and in trance performances of réyog in places like Madiun) open coconuts with their teeth and drink the milk, which is regarded as a spirit offering (sajèn). But in a nontrance performance such as a Ponorogo-style réyog, water is perhaps a more appropriate drink for the defeated, playful "cat" than the magically powerful coconut milk. 
grabbing the coconut and throwing it away, so that he had to chase it. But as soon as he managed to get hold of it, it was taken from him, making him appear a weak, impotent, amusing figure.

Once again, the conflict was not resolved in terms of clear victory and defeat. The "cat" was simply proven inferior to the "mouse" for the time being. The prolonged closing scene ended, like all the others, with a suwukan, a postlude, and musical silence.

Like any other music, réyog music consists of nothing but sound waves in the air. As such, as has often been stated, it is incapable of expressing anything extramusical. There is no doubt, however, that réyog music arouses strong emotions in an abangan (nominally Musiim, influenced by pre-Islamic ideas) audience, who perceive it in terms of learned responses established over time. Many an outsider, even with the best will in the world, cannot feel the emotional excitement of the music as intensely or in terms of such specific connotations and habitual responses as an abangan villager from Ponorogo. But the lack of response among many outsiders is not only because they have not been in a position to absorb the accepted connotations of the music; they also put up specific aesthetic, moral, or political barriers. Even Javanese of a non-abangan background may feel little emotional response. Priyayi (white collar and aristocratic elite) tend to regard réyog music as primitive, boring, repetitive and in bad taste when compared to alus court music; ${ }^{16}$ santri (devout Muslims) regard it as morally inferior to Muslim music, because it is associated with the preMuslim beliefs of the old Javanese religion (agama Jawa); and many city-dwellers and modernists regard it as an unhealthy opiate, sustaining backward ideas and irrational behavior among village people.

Music alone cannot express a specific, differentiated emotion. Reyog music cannot reflect the strangeness and aloofness of the jaran kepang, the exhilarating humor of a certain clown, or the excitement of a specific sexual encounter. Jatizan'17 music cannot even express anything as specific as the elation of victory, except when combined with a more specific art form, such as drama. But through contrast and sameness, waxing and waning, tension and release, and various progressions, timbres, and rests, it can stimulate varying degrees of emotion in the listeners, including exhilaration and excitement.

Characteristic of much Javanese music is a qualify of calmness and a steadily controlled level of emotional content. Such alus traits are not dominant in gamelan réyog. Yet reyog music still has associations with the concept of cosmic dualism prevalent in the more alus court music. Réyog music combines strong elements of chthonic unruliness with a background of cosmic musical order. It does not, for

${ }^{16}$ In his "Agrarian Radicalism in Java," in Claire Holt et al. (eds.), Culture and Politics in Indonesia (Ithaca: Cornel1 University Press, 1972), p. 85, Sartono Kartodirdjo writes that, although the priyayi and abangan streams are really two sides of one cultural coin, "built into priyayi values there is a deep contempt for village life."

17Jatizan is the generic term for Javanese hobby-horse drama. 
example, usually have long periods between gongan (strokes of the gong).18 Whereas the most lofty courtly works (gending ageng) may have extraordinarily long gongan (up to 1,024 beats), réyog pieces mostly have only eight or a maximum of sixteen beats (keteg) per gongan. Nor does réyog music have a strongly delayed final gong stroke after a pronounced suwukan, as in most alus music, when all the lesser instruments in the gamelan hierarchy wait respectfully for the great gong to sound before playing their final note. Réyog music quickly builds up and sustains a high level of excitement among its listeners. It frequently waxes and wanes in tempo, achieving climactic points or falling off near the end into a period of emotional release. On the one hand, the music sustains the listener's emotive and cognitive interest by its eventful slomprèt and kendang parts. On the other, it achieves a simultaneously mesmerizing effect through the reiterative parts for angklung, kenong, tipung, dor, and kempul. Although Ponorogo-style réyog is not a trance form as it is in other areas, its music belongs to the genre of Javanese trance music.19 The essence of this ensemble style is the dialectical relationship between musical libertarianism and rigidity.

Some Javanese music features a high degree of rigidity, as in the case of those archaic Javanese compositions which were once played in the courts on such occasions as tiger-baiting ceremonies (rampok macan) and tiger-buffalo fights (adu-adu macan). ${ }^{20}$ For example, the gamelan kodok ngorèk which, like the gamelan réyog is a "masculine," outdoor ensemble, consists of drums and gongs playing simple, stereotyped patterns along with a two-tone melody of "obsessional syncopation"21 on the kettles (bonang). The only slight variation is a two-fold change in tempo. On the other hand, some Javanese music, whether alus or kasar, almost totally lacks the element of rigidity, triumphantly displaying a high degree of libertarianism, as in the singing of bawa (introductions to gending) accompanied by the delicatly rhapsodic, floating-key metallophone gendèr. The vocalist here, like the slomprèt in réyog, is allowed a high degree of rhythmic, metric, ornamental, melodic, and intonational variability.

The combination of these two conflicting elements, as in gamelan réyog, results in a totally different effect from either one by itself. The quantitative change produces a qualitative one. The dialectical relationship between the regular, unchanging element and the variable component underlines the dualistic effect of the music.22 The musical dualism reflects the dualism of the cosmos.

${ }^{18}$ In réyog the "strong" kempul plays a part equivalent to that of the main gong in the large concert gamelan. In this essay I use the term gongan to denote the period of time between the playing of two strokes on the "strong" kempul.

${ }^{19}$ See M. Kartomi, "Music and Trance in Central Java," Ethnomusicology, XVII, 2 (May 1973), pp. 163-208, for more examples of Javanese trance music.

${ }^{20}$ In the $a d u-a d u$ macan, the buffalo represented royal authority and cosmic order while the tiger was a symbol of chaos and the underworld. The music, however, in its rigidity, was thus "biased" in favor of royal authority, neglecting as it did the chthonic elements. Réyog music, on the other hand, portrays both, and is therefore much more a mix of opposites than the music of the archaic orchestras.

21 Jaap Kunst, Music in Java (The Hague: Nijhoff, 1949), I, p. 238. A third kettle plays another continually recurring tone (pancer) in kodok ngorèk.

22Réyog orchestras have featured this dualistic quality for decades, as is 
The slompret 23 bears the main melodic responsibility in the ensemble. It improvises adventurous and variable melodic ideas, employing glissandi, whimsical incidental ornamentation, miring ${ }^{24}$ pitch alternation, sliring 25 deviations from the main established pitch levels, a great variety of rhythms, and rhythmic anticipation of and lagging behind the main beat. The constant flow of slomprèt sound, unbroken by rests, is achieved by the player's controlled flow of breath into the bamboo mouthpiece (kipik). The player stores his breath in his cheeks and emits it slowly while inhaling through the nose. His blownout cheeks touch the round coconut wings attached to the mouthpiece. The conical pipe of the slompret has a detachable flared bell at the end; the player blows through this onto a double reed of concussion lamezzae 26 (thin vibrating bamboo plates cut into a fan shape and tied together in two sets of three).

The slompret alone establishes the tone system and modal qualities of the music. Although some sections of réyog music are too 1 imited tonally to reflect either of the two main Javanese tone systems (sléndro and pélog), most of the melodies are in the seven-tone pélog. More specifically, they are in pélog pațet barang (called pélog patet miring in local East Javanese parlance), with strong implications of the

clear from references in Pigeaud's Volksvertoningen. A Ponorogo orchestra described there by Darminta (p. 187) included a slomprèt, two angklung, a large kendang, a timplung or tuntung (a small, stick-beaten drum), a kempul, and two kenong. In Surakarta, an orchestra consisted of a slomprèt, kenḍang, kețuk, kenong, and kempul (p. 191). An ensemble in Kediri had two or three angklung but no slomprèt (p. 195), but another ensemble in Banyuwangi had a slomprèt, a kenḍang, a saron, a gendèr, and a gong (p. 190). Staugaard described an ensemble in Ponorogo consisting of a flute (suling), two angklung, two gong, and a drum ("Koeda-képang," p. 422). Kunst reported a réyog-like (but Barong-less) performance in Désa Pakem, north of Jogyakarta, using suling, logdog or réog (drum), penitir panengah (kettles), and gong (Music in Java, I, p. 285). Kunst transcribed the music, which was in pélog tonality (p. 285).

${ }^{23}$ The slomprèt could be an old indigenous Javanese instrument, but the similarity of its construction to shawms in Sumatra, India, and the Middle East suggests that it probably is historically related to them. The details of wind instruments in Barabudur and Prambanan temple reliefs are insufficient to establish them as shawms as opposed to single-reed flutes. Kunst was of the opinion that the slomprèt was possibly used as an instrument of war in the Hindu-Javanese period (when it may have been called by such names as prèrèt and gemprèt). See his Hindu-Javanese Musical Instruments (The Hague: Nijhoff, 1968), p. 29. But this does not tally with Jairazbhoy's historical discussion of the related instruments shanaiz and nägasvara in India and the surnāy in Arabia (from which the Malayo-Sumatran samuai is probably derived). According to textual references, the instrument was probably introduced. into South India after Muslim incursions from the Middle East in the fifteenth century. An auspicious instrument, it was then adapted to Hindu folk traditions and used in temples and at festivals, sometimes to accompany folk dances. See N. A. Jairazbhoy, "The Oboe in India," Ethnomusicology, XIV, 3 (September 1970), pp. 375-88. If Jairazbhoy is correct, the instrument may have reached Java no earlier than after the end of the Hindu-Javanese period.

24Miring (1iterally, "slanting") means constantly deviating in pitch.

25:Sliring means inconsistently deviating in pitch.

${ }^{26}$ The term concussion Zomezlae is used in A. Baines and K. P. Wachsmann, "Classification of Musical Instruments," Galpin Society Joumal, 14 (1961), pp. 3-29. 
closely related pélog pațet manyura. 27 The slomprèt player sometimes teases the tonal sense of the listener by an ambiguous combination of slendro-like intervals and deviating pelog intonations. In the patet barang sections, tones 5 and 1 are sometimes lowered to produce sléndro-1ike intervals of a third (

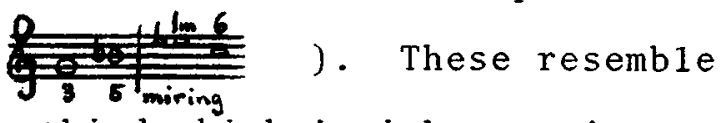
another sléndro-like interval of a third which is inherent in paṭet barang ( The patet manyura sections, on the other hand, usually have an unambiguous pelog quality. This pelog-sléndro ambiguity in the patet barang sections, combined with the altering pitch of tone 2 and the modal mutations, give the music a quality of continued tonal uncertainty and surprise.

The slomprèt line in "Pambuka" (transcribed in full below) consists of twenty melodic units, which I will call gongan. The large melodic sections of the piece consist of five groups of four gongan each (gongan 1-4, 5-8, 9-12, 13-16, and 17-20), each recognizable by the rhythmically similar slompret opening ( $\rho \cdot \rho$ in gongan 1 and 5 , $\rho \int \delta$ in gongan 9 and 13 , and $p$ epep in gongan 17) and the emphasis on the main interval of a fifth (6-3). Apart from the tonally rather wayward buka, which establishes the principal pațet manyura tones ( $\left.\begin{array}{lllll}6 & 5 & 3 & 2 & 1\end{array}\right)$, the gending proper is based on the main patet barang tones $\left(\begin{array}{lllll}7 & 6 & 5 & 3 & 2\end{array}\right)$ with an occasional incidence of tone 1 (as in gongan 4-6 and the epilogue) and one instance of a sliring tone 4 (in gongan 7), the highest pitch reached in the piece. Unlike much pațet barang music, tone 5 is mostly avoided. 28 Tone 7 is not used in the buka but occurs very frequently (in $71 \%$ of the bars) during the main body of the piece, giving it its distinctive pațet barang character. But the main tones are 6,3 , and 2 , which occur prominently in the buka and in almost every gongan.29 Tone 2 (the preferred initial and final tone) alternates in miring fashion every two gongan between the higher (F\#)

27pélog patet manyura "is felt as a kind of supplementary pațet, related to pațet barang, in which, however, the tone barang (7) is replaced by the tone bem (1) as principal tone" (Kunst, Music in Java, I, p. 88). It is not really a independent pațet like pațet nem, lima, and barang.

${ }^{28}$ Tone 5 appears only in the buka and in gongan 3-4, 11-12, 15-16, and 19-20.

29 My findings in this small sample of pieces support both the theoretical hierarchy of tones proposed by Kunst, Hood, and others, i.e., that the principal tones of pațet barang are 6,3 , and 2 (not 6,2 , and 5 as in Becker's findings) and the conclusions of Becker that the preferred final tones in pațet barang are 2 and sometimes 6 (the final tone in the case of réyog meaning the tone coinciding with the last strong kempul stroke), not mainly 6 , as in Hood's findings. This theory of réyog music does not support Hood's hypothesis (which applies to courtly gending, not to village music) that the buka is the kernel of the musical ideas appearing in the piece proper. Buka in réyog tend to be very irregular and at times present material which contrasts in some respects with the gending proper. See Kunst, Music in Java, p. 95; Mantle Hood, The Nuclear Theme as a Determinant of Patet in Javanese Music (Groningen: Wolters, 1954), p. 222; Judith M. 0. Becker, "Traditional Music in Modern Java" (Ph.D. dissertation, University of Michigan, 1972), pp. 167 and 171. 
and lower (FG) pitch levels, giving a continual quasi-modulatory effect. ${ }^{30}$ Tone 6 most frequent1y coincides with the strong kempul (fourteen times) thus emphasizing its theoretical importance, but tone 7 often does also (nine times). Tone 3 occurs very frequently and is prominent as the highest theoretical tone of the range.

The slompret variations tend to concentrate on a particular configuration of tones before moving to another configuration. For example, in "Pambuka" the slompret concentrates on a block of five tones $\left(\begin{array}{lllll}1 & 2 & 3 & 6 & 7\end{array}\right)$ in gongan 3 , half of $4,7,8,11$, and 12 ; four tones $\left(\begin{array}{llll}2 & 3 & 6 & 7\end{array}\right)$ in gongan 1 and 2 ; and three tones $\left(\begin{array}{lll}2 & 3 & 6\end{array}\right)$ in gongan 13 and the postlude. This cuts across the other regular change of tonal material in every two gongan, from the higher-pitched tone 2 , with a strong patet barang flavor emphasizing tone 7 , to the lower-pitched tone 2 , with a strong patet manyura flavor, emphasizing tone 1 . Two types of melodic cadential formulae were apparently in the slompret player's mind, leading up to each strong kempul stroke. One of the formulae belongs to pațet barang and the other to its close relative, patet

manyura. The main cadential formula,

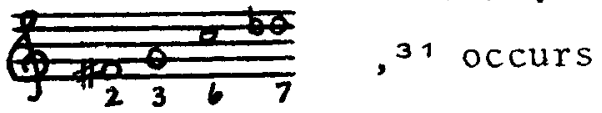

eleven times in "Pambuka."32 Although this formula occurs in retrograde descending form within gongan, it always appears in ascending form at cadential points.

The other formula is
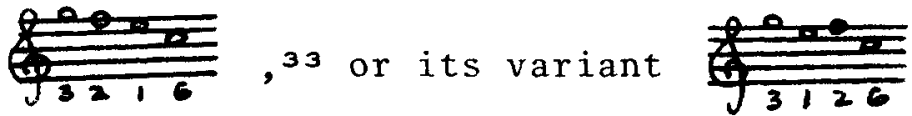

Occurring nine times at cadential points in "Pambuka,"34 it is sometimes extended, as in gongan 3 :

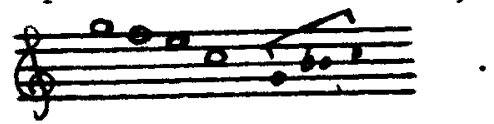

The same formulae recur throughout the other six pieces, patet barang characteristics dominating in some (for example in "Ponoragan") 35 and pațet manyura in others (for example in "Sontoloyo"). But since the colotomic patterns of pieces after "Pambuka" are less complex, less

${ }^{30}$ There is, however, no regular alternation between the higher and lower tone 2 in "Pujangganom" unlike, for example, "Pambuka" and "Barongan."

${ }^{31}$ Perhaps this formula may be regarded as a variant of Hood's T3 formula:

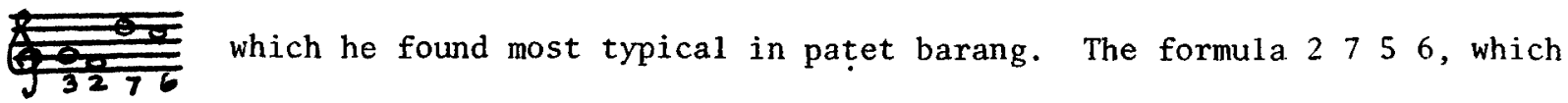

Becker found common in her pațet barang material, is not typical in my examples of réyog music.

${ }^{32}$ At the ends of gongan $1,2,5,6,9,10,13,14,17,18$, and 20 . Tone 6 enters late in the formula at the end of gongan 1 .

${ }^{33}$ This formula is the same as Hood's T3 formula for patet manyura, except that its shape as played on the saron is

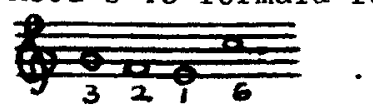

${ }^{34} \mathrm{At}$ the end of gongan $3,4,7,8,11,12,15,16$, and 19 . In gongan 6 , sliring tone 4 substitutes for 3 .

35Ponoragan means "in Ponorogo style." It is apparently an old réyog musical title. A gending "Panaraga" is referred to in Volksvertoningen, p. 188. 
emphasis is placed in those pieces on such formal characteristics as cadential formulae, which often appear in incomplete form (as in gongans 1-4 of "Ponoragan").

The rhapsodic slompret part in "Pujangganom" (see below) establishes patet manyura qualities from the beginning. Tone 1 is established by repetition, tone 3 by a sustained vibrato, and tone 2 by a glissando down a ninth. After this emphatic beginning the tones are used sliring-style in the piece proper (e.g., lowered tone 2 in gongan 3 and lowered tone 1 in gongan 4), with bold successions of ornamented and at times syncopated leaps (e.g., By way of contrast, straightforward shifting figurative passages as in the postlude of "Pujangganom" , oscillatory patterns like those near the end of "Sontoloyo" passages of triplets containing auxiliary notes as in "Jaran Kepang," excerpt (a)

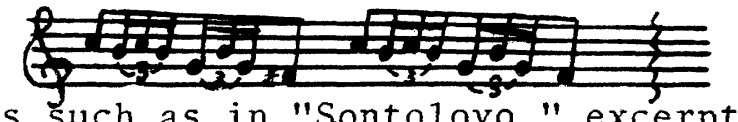
and highly singable recurring motives such as in "Sontoloyo," excerpt (b) and in gongans 7-8 and 11-12 of the "Pambuka"

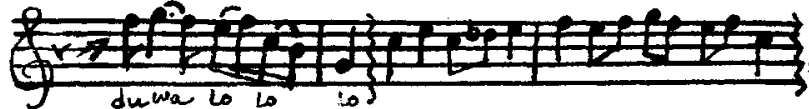
a11 exemplify the repetitive elements in slompret playing. Using stock ornamental touches such as shakes, trills, turns, acciaccaturas, and a. variety of glissando types (e.g., $-p-p p_{2} \rho$ ), the slomprèt player transforms well-known melodic ideas of the réyog idiom into a continually changing continuity of sound, consisting of surprising quirks and ambiguities ${ }^{36}$ on the one hand and relatively stable, straightforward passages on the other. Analysis thus shows that the slompret part is really not as anarchic as it seems.

The slompret player always ends a piece with a short, melodically descending, gently rhapsodic, free-metric postlude which is said to carry the soul of the gending to heaven (nyawa gending minggah swarga). These postludes frequently reiterate the preferred final tone (2), and often contain the descending form of the main patet barang melodic formula $\begin{array}{lllllllll}7 & 6 & 3 & 2\end{array}$ and patet manyura formula 32216 , or a variant thereof. Except in the unusually short postlude to "Barongan," the slompret is accompanied by a relatively free-rhythm kenḍang part, producing a fascinating, ever-changing sequence of timbres.

While the piercing, dominating line of the slomprèt provides the main element of melodic variability in reyog music, the kendang makes a major contribution of rhythmic variability, its subtlety emphasized

${ }^{36}$ For example, one has the ambiguous feeling of being simultaneously in patet barang and manyura in gongan 3 and 4 of the piece "Pujangganom." There we find not only both miring intonations of tone 2 but also the incidence of tones 1 and 7 (one of which is usually strictly optional) in close succession, both in sliring intonations. 
and enhanced by the continually changing pattern of drum timbres. To obtain a variety of timbres, the player plays with his palms and/or fingers various parts of the taut edges and the more elastic inner part of the skin of each drum end, sometimes playing both ends together. The kendang Ponorogo is exceptionally long, heavy, and wide compared with most Southeast Asian drums, and can produce sounds of great intensity, brilliance, and carrying power.

Usually the kendang enters during the buka, either solo or accompanying the slomprèt, after which the tipung provides a steady, offbeat foil to the virtuoso, ever-changing rhythmic line of the kendang. The most spectacular drumming in these examples appears in "Pugangganom," where the two drums interlock in very fast, loud figurations, with displaced accents and triplet, quintuplet, and sextuplet figures teasing the rhythmic sense of the 1 istener. Mostly, the main drummer plays a dominating role in the ensemble; he does not merge with and subtly control the outlines of a performance as the drummer does in most alus music. But sometimes the drummer gives an effect of rhythmic continuity leavened by continual timbral changes, in a free-rythmic ciblon style (ciblon is an onomatopoeic description of the sound of girls rhythmically splashing the water as they bathe in the river). Explosive bursts on the drum are sometimes intended as signals to the ensemble to speed up or to slow down, at other times to accompany a dramatic activity or character-change on stage, or simply to heighten or lessen the tension during acrobatic and clown scenes. In fact, the drums in reyog play the roles that kendang and keprak do in most other theatrical dance music. (The keprak emphasizes and directs the rhythm of the dancers' movements.) When the reyog drummer decides to end a piece, he gives a loud rhythmic signal to the ensemble telling the players to slow down, and end after the final strong kempul stroke.

Routine elements of musical continuity are provided in strict meter by the tipung, the interlocking dor, angklung, kenong, and kempul. The hocket patterns of male voices in the dor sometimes reach a highly impressive sonority, produced with breathtaking precision of the interlocking, single-note parts. Vocal interlocking parts are rare and instrumental interlocking parts common in Southeast Asia. Interlocking elaboration may have originated in the ancient practice of koteekan, where several women pound rice with the poles beating down regularly into a trough and producing a complex interlocking series of rhythms. In réyog music, the single-pitch angklung interlock to produce a steady two-tone alternation, doubling the interlocking two-tone melody of the kenong (for example, in the "Pambuka" and

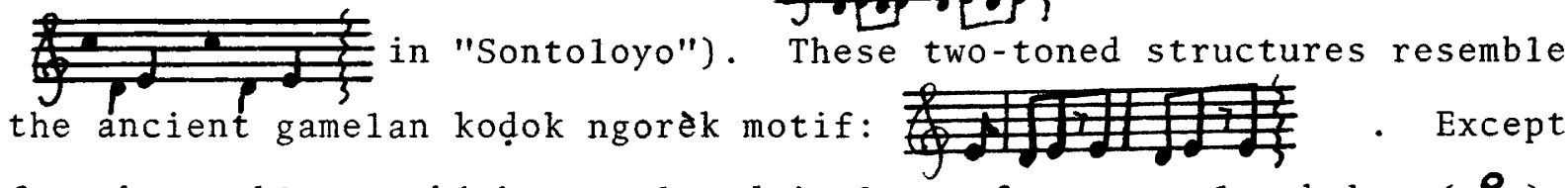

for the angklung, which are played in 1ong, free tremolo shakes ( $f$ ), the interlocking instruments, usually ending on the final strong kempul stroke, do not feature in the postlude.

Indicative of the free nature of réyog music is the variety of colotomic patterns contributed by the two kempul. The colotomies of standard gamelan music as practiced in the courts and in most city gamelan today are not characteristic of reyog music, which has its own 


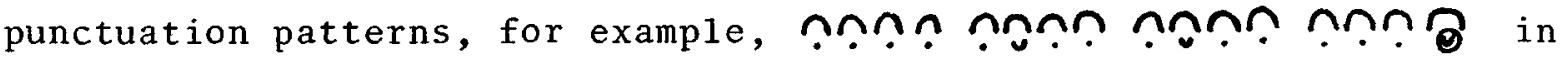
the sixteen-beat gongan of the "Pambuka," eight-beat gongan of "Ponoragan," nn. $n$. i in "Sontoloyo," and nฺnṇnṇng nṇınnnnn in "Pujangganom," "Jaran Képang," "Barongan," and "Kucing-kucingan."37 The kenong plays twice as frequently in the last four pieces as in the "Pambuka," where in turn the kenong plays twice as frequently as in "Sontoloyo." The syncopated kempul part (resembling Zancaran ${ }^{38}$ ) and the relatively long gongan of the "Pambuka" make this piece the most complex of all.

The other réyog pieces have colotomies resembling sampak and srepegan, although the kempul are less active than in the stock sampak of classical, courtly wayang. The kenong activity of these reyog pieces resembles that of the classical sampak, however, in that the kenong is played on every beat (keteg), as in the "Pambuka," or on and between every beat, as in the last four pieces of the reyog. "Sontoloyo," on the other hand, is a variation of the stock srepegan-type colotomy, in which the kenong usually plays on alternate beats.

It seems, then, that reyog music is comparable in certain respects to the fastest and most violent forms of dance music in wayang. Like much other Javanese dramatic art, the musical form of a whole performance is episodic and suite-like, divided up by brief silences, with no transitions between musical sections. It is based on a Javanese sense of time which Geertz cal1s "punctuate,"39 resulting in a fragmented rather than a sustained flow of audience attention. It also bears some relation to the music of archaic outdoor gamelan preserved to this day in the courts.

But reyog and other village music are not, as some would say, simply rudimentary, primeval, unchanging musical species from which the courts developed their more sophisticated, more "valuable" styles. They are certain1y not a cheap, banal imitation of superior urban courtly music either. Two-way artistic influences must always have exerted themselves between court and village. Reyog, like other village-based musical art, has its own unique characteristics, including its specific dialectical ensemble style, its own particular combination of instruments, the choral interlocking style of the dor, its specific

37 denotes a kenong stroke, $U$ denotes a weak kempul stroke, $(2$ denotes a strong kempul stroke, and . denotes a musical rest. Except for () which is my symbol, these symbols are based on the Javanese kepatihan system of musical notation. . The kempul parts in the transcription of the "Pambuka":
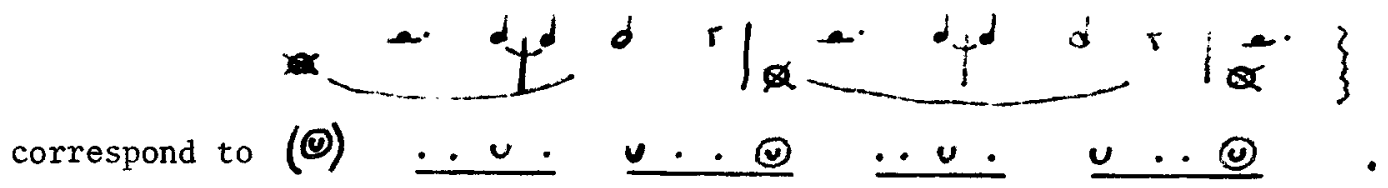

${ }^{38}$ Lancaran is a stock form of gending in which gongan of sixteen saron beats are subdivided in syncopated fashion by the kempul.

${ }^{39} \mathrm{Cliff}$ (f) Geertz writes of the Javanese tendency to "shift sharply from one kind of activity to another"; The Religion of Java (Glencoe: The Free Press, 1960), p. 12. J. L. Peacock observed the relevance of this to ludruk theater. See his Rites of Modernization (Chicago: University of Chicago Press, 1968), pp. 67-68. 
climactic qualities, and its characteristically high level of excitement. Reyog represents a tradition of artistic activity that can lay claim to great age and considerable quality. Although it cannot be so proven, due to the lack of musical source material, a degree of musical change is bound to have occurred throughout its history together with changing social, artistic, and political conditions. But whatever the changes, reyog remains a distinctively rural artistic form.

Javanese peasant communities have for too long been portrayed as culturally inert, primitive, unchanging, and artistically dependent upon the courts, a view that is reflected by the well-known saying, biased in favor of the priyayi, that "the towns have their order and the villages their customs" (nagara mawa tata, désa mawa cara). 40 Unlike the literate, urban, historically conscious courts, the villages cannot usually produce tangible sources to show the continuity and change of their art forms over time. In this respect, however, reyog Ponorogo is in a slightly better position than most. Although primarily rural and abangan, it can point to some aristocratic connections and a few historical sources. The religio-philosophical ideas inherent in réyog place it clearly in the mainstream of Javanese abangan-priyayi thought, giving it complex and far-reaching meaning.

Reyog Ponorogo as we know it today is a combination of several separate traditional elements. The jaran kepang dance, for example, possibly had a military origin, based on displays of prowess by cavalry, or military exercises on horseback. Or perhaps it began with the imitation of the activities of cavalry by children and/or adults, who thus conceived the idea of dancing with bamboo hobby-horses. In any event, at some time it became associated with various ancient magicoreligious elements, including eroticism and fertility beliefs in the Ponorogo region, and belief in the possession of entranced dancers by animal and ancestral spirits in other areas.

The word reyog possibly derives from the name Angréyok, used by the court poet Prapanca in the fourteenth-century poem Nägara Kertagama. According to Pigeaud, Angreyok "is suggestive of a soldierly spirit, the modern Javanese reyog dancing performance, a sham fight, probably is to be connected with ancient military lore."41

Although one can be sure that most elements of reyog Ponorogo are very old indeed, the earliest known references to art forms resembling it are contained in the serat cabolang, a poem which was probably written in Surakarta in the late eighteenth and early nineteenth centuries. ${ }^{2}$

${ }^{40}$ Sartono Kartodirdjo argues in favor of this interpretation of the saying in "Agrarian Radicalism in Java," p. 85. Some Javanese, however, dispute it, claiming the saying merely means that different places have different customs.

${ }^{41} \mathrm{Java}$ in the Fourteenth Century: A Study in Cuztural History (The Hague: Nijhoff, 1962), IV, p. 532. The name Angréyok is found in the first stanza of Canto 9. Pigeaud mentions that other military names have also survived to modern times, for example, pangalasan (royal.guardsman) and tamtama (the name of a company of soldiers at the Central Javanese court).

42 Its contents are described by Pigeaud in "De Serat Tjabolang en de Serat Tjentini, Inhoudsopgaven," Verhandelingen van het Bataviaasch Genootschap, LXXII, 2 (1933), pp. 1-89. The Serat Cabolang was intended as a preface to the Serat Centini. 
The hero of the poem--a student named Cabolang, son of a rural seer (kyahi)--observed certain ceremonies and took part in erotic scenes during his wanderings in the Ponorogo area. Clear references are made to strong men called warok who associate with handsome young boys called gemblak. The poem describes a circumcision procession in which twenty jaran kepang dancers and five gendruwon43--a11 warok--(two with sickles, two with swords, and one with a woodman's axe)--took part, with three transvestite boys (called jatiz or jatilan) in the middle. The name réyog was given to all the masked and horse dancers. The boys to be circumcized followed the jaran kepang dancers, who sang to the accompaniment of a srunèn orchestra consisting of slomprèt, angklung, kenḍang, kemong, and kempul.44 Mention is made of a fight between réyog troops and a contest between the monster (the Barong, presumably), the masked gendruwon, and the hobby-horse dancers.

The Serat Cabolang indicates that the Ponorogo area was quite rich in transvestite art forms based on the warok-gemblak phenomenon in the late eighteenth century (and presumably earlier than that, considering the time it would normaliy take to develop such forms). It mentions transvestite performances of serious feminine dances 45 and the practice of transvestites singing as pasindèn (female vocalists), ${ }^{40}$ which resemble elements of Zudruk, the main form of modern East Javanese musical theater. It also refers to a social dance party (tayuban) with guests taking transvestite partners, 47 as is still the case in some modern Javanese tayuban parties. Transvestite art was popular despite the fact that Ponorogo was an area known for its Muslim student houses (pesantrèn), the teachers and students of which might have been expected to disapprove of "immoral" art forms. Yet Pigeaud points out that the attitudes of mystical Muslim brotherliness may even have helped to spread some of these transvestite forms.48

A warok genggek is described in the poem as wearing remarkable, showy clothes in black, white, and red, with a very large headcloth, an iron stick, and a large knife. The text is not very clear about the character of the warok, but Pigeaud disputes the view commonly held

${ }^{43}$ Gendruwon is another name for Pujangganom, also known in Ponorogo as Kedokan, Bujang Anung (outstanding young man), and Pujangga Anom (young scholar). Other names for this character include Wongwongan in Pacitan and Blora, and Jakalodra (wild man) in Jogyakarta and Blora. He is also known as tjèpètan, țètèk mèlèk or -mĕlèk, budjangganung or -ganong, and budjangganom or -ganung. See Volksvertoningen, pp. $134,186-87,194,420-21$.

44 Ibid., p. 303 .

${ }^{45}$ The poem refers to Cabolang and his companion dressed as girls and dancing "like heavenly nymphs," singing to the accompaniment of terbang (frame drums) and kendang. They performed, among other things, the feminine bondan dance, with umbreilas, as can be seen in Java today. Ibid.

${ }^{46}$ Twelve boys made dance formations in fours, holding fans and betel nut in either hand, taking turns to sing as pasindèn. After each dance, the warok cooled their gemblak with fans. Ibid.

${ }^{47}$ The spectators at the tayuban party are said in the poem to have danced with the two transvestites (Cabolang and his friend) individually for payment, after drawing lots to avoid arguments as to which guest should begin. Ibid.

$$
{ }^{48} \text { Ibid., p. } 305 .
$$


by colonial Dutch authorities and some Javanese that he was a sexual evil-doer, beggar, or robber. The warok apparently hired gemblak at the age of about fifteen for a year or so, giving them board and lodging, and, if they were attractive in appearance, two or three buffaloes. Each gemblak lived in his owner's house as a servant and young friend, ready to be hired out as a transvestite dancer. Jealously guarding their gemblak, the warok fought over them if necessary and even carried them on their backs at market for safety.49 Sometimes a warok was a leader of a wandering group, shunning normal social intercourse. He would take his gemblak with him on his adventurous trips, looking for trade and work opportunities, visiting hermitages, searching for forest products, and hunting and fishing on the way. Often he would work as a conjurer or a musician in the street gemblak performances he 1 ed.50 Warok were also reported to be kenong players in their reyog troupes.51

Throughout this century, warok have been known as magic practitioners who often led réyog troupes, assuming various roles as clowns, Pujangganom, Barong, 52 or musicians. They are still described as strong, powerful men, who possess magic power of a sort that would be lessened by sexual relations with women.53 This is given as an explanation for their reputed homosexual relations with gemblak. But transvestitism and the associated phenomena of homosexuality should not be seen as basically illicit, despite the overtones of disapproval among some modernists and santri today. Perhaps transvestite reyog is partly to be understood as social therapy, as a means of helping people in a marginal state 54 such as homosexuals and transvestites by giving them socially acceptable ways of expressing their sexual desires. Presumably, some gemblak may have a more than professional interest in the true transvestite's role and thus gain emotional relief and enjoyment from wearing women's clothes; possibly, some are also homosexual. Some gemblak eventually acquire wives, while others prefer to remain with their warok, partly in order to benefit from his magic aura. Some warok are certainly homosexuals. Bisexuals and even heterosexuals may also delight in or enjoy watching seductive situations such as these, as one may notice at certain tayuban parties.55 As Peacock intimates,

${ }^{49}$ At 1 least until recently, boys in Ponorogo were repeatedly told by their parents to avoid being kidnapped by warok, who were regarded as dangerous, and to hide from their sight, for example, at réyog performances.

50This paragraph is based on Volksvertoningen, pp. 302-4.

51 According to Darminta in ibid., p. 301.

52According to Darminta, ibid., a gemblak in a réyog Ponorogo show early in this century was the darling (keZangenan) of the Singa Barong and the gendruwon (Pugangganom). For warok and gemblak as clowns, see note 10 above.

${ }^{53}$ In Java as in other parts of the world, ". . . ritual had to be protected from female pollution, the male officiants . . abstaining from sexual intercourse. . . " See Mary Douglas, Purity and Danger (London: Routledge and Kegan Paul, 1966), p. 152 .

${ }^{54}$ This means "people who are somehow left out in the patteming of society." Ibid., p. 95 .

${ }^{55}$ Such an observation was made to me by a Javanese man who attended a tayuban party after a circumcision in the late 1950s. Certain male guests kissed the gemblak who sat on their knees. In return, the men gave them food and other things they. asked for. 
when people want to do something not normally acceptable in their society, they sometimes do it in art form.56

The transvestite element of reyog may be seen not only as a way of coping with life but also as a way of representing a frame of mind.57 In the context of Javanese religion and ritual, it becomes respectable and acceptable. The ancient Indonesian tradition of the hermaphrodite as a sacred symbol of the unity of the cosmos has been expressed repeatedly in the sculpture, dance, drama, and rituals, as well as in the concepts of morality, kingship, and power.58 The unity of the cosmos includes the philosophical unity of the sexes. Semar, for example, the much-loved divine clown of the wayang, is neither exclusively male nor female; his dualistic being reflects the dualistic cosmos and the complementarity between heaven and the underworld. Only the partly transvestite bissu priests are allowed to guard the sacred regalia in the Buginese courts. Lènggèr, tlèdek, ronggeng, beḍaya, srimpi, bonḍan, and other feminine Javanese dances, as well as sinḑèn singing roies, have traditionally been performed not only by girls but also by boys impersonating girls. Reyog and ludruk are but two of the best known of many transvestite art forms. Attributions of indecency and illicitness seem inappropriate in the face of such a widespread phenomenon. The moral question is less relevant, in fact, than the alus-kasar issue. Very alus feminine art forms normally assume a degree of kasarness when performed by men (though perhaps only slightly in the case of the best sinden singing in ludruk), which in turn contributes an element of increased eroticism and much-appreciated humor.

Javanese visual and performing arts (including poetry) have been suffused with eroticism of various types and associated with rites of fertility. Not only are the many forms of sexuality regarded as forming a unity, but every person is in fact bisexual to a degree, combining both feminine and masculine characteristics. Given the connection between bisexuality, sexual power, and fertility in the Indonesian tradition, the performance of transvestite art forms as fertility symbols at weddings is not as anomalous as it may at first seem. The

56Peacock, Rites of Modemization, pp. 204-5.

57The notion that religion represents a frame of mind is more emically Javanese than the view that it is a way of coping with life. Trance art forms, for example, allow people openly to express forbidden desires and to release tensions through uninhibited behavior. But trance art is also an expression of a world view. The distinction between these two approaches to understanding religion is made by Clifford Geertz in Islom Observed: Religious DeveZopment in Morocco and Indonesia (New Haven: Yale University Press, 1968), pp. 91-95.

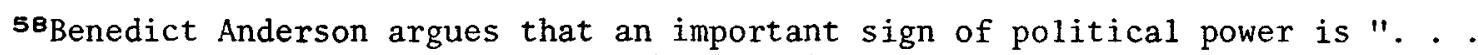
the ability to concentrate opposites. The classical iconographic symbol of this is the combination of male and female. In ancient Javanese art this combination does not take the form of the hermaphrodite of the Hellenistic world, an ambiguous transitional being between the sexes, but rather the form of being in whom masculine and feminine characteristics are sharply juxtaposed. One finds, for example, in the ardhanari type of image that the left side of the statue is physiologically female, the right side male. The essential characteristic of this combination of opposites is not their merging but their dynamic simultaneous incorporation within a single entity. Thus the ardhanari image expresses the vitality of the ruler, his oneness, and his center-ness . . ." (see his essay, entitled "The Idea of Power in Javanese Culture," in Culture and Politics in Indonesia, p. 14). 
gemblak personifies the philosophical unity of male and female in a way similar to the banana stems on the wedding house door, the leaf-flower arrangements (kembar mayang), the egg-crushing ceremony, and the other fertility rituals still carried out at some Javanese weddings. Appropriately, too, at least until recently, transvestite réyog was still performed at circumcision celebrations, the animist and sexual connotations thereof overlaid by a thin Muslim veneer.

The Singa Barong figure also has its cosmic connotations as the great chthonic creature who plays a major part in the eternal struggle. He may be called Rajawana, meaning Lord of the Jungle. The view has been proposed that the evolution of the Barong in Java differs from that in Hindu Bali, where the "barong keket retains the status of a protective deity. . . . In Islamic Java, however, the singa barong could not retain any kind of divine status. If once the singa barong did indeed occupy a more exalted position, he has been brought down to that of a dangerous wild beast fought in the woods by emissaries of a legendary prince." 59 There could be a degree of truth in this interpretation, but the view of the Barong as a figure of prosperity and goodwill has not been lost in réyog by any means. For one thing, the character of the great Barong in a reyog pageant is much more good-natured than that of the tiger-king in the "Babad Reyog Ponorogo." For another, 1ighthearted pairs of Barong have made their grand entries in duo for several decades at least for the sake of enhancing the beauty of the pageantry. A pair of Barong was reported in a Ponorogo performance several decades ago.60

The people of Ponorogo say that their Barong represents the Lord of the Jungle, combining the characteristics of three royal animals-the peacock,61 the (mythical) lion (singa),62 and the tiger. The resemblance in shape between the revered symbol of nature and the universe (kayon) in wayang kulit and the Barong Ponorogo headdress suggests that a symbolic connection is felt between the ancient kayon and the Barong.

They also say that the peacock, lion, and tiger were the symbols of Javanese regalia in the past. And indeed, peacocks feature in a description of a state procession in the old Javanese poem Nawanatya, written in the fourteenth century: "There follows the state-palanquin of the Prabhu and Consort in the shade of the peacocks' feathers sunshades with golden knobs,"63 and as a simile for royal singing in the Năgara-Kertăgama: "The Prince's singing is moving, causing amazement, touching. A peacock carolling on a tree is the likeness for it... "64 And the singa appears as a symbol in the regalia at the posthumous

59Holt, Art in Indonesia, p. 108. 60pigeaud, Volksvertoningen, p. 190.

$61 \mathrm{M}$. Covarrubias writes that in Bali "there are also extraordinary Barongs that are covered . . . with peacock feathers instead of the usual fleece of horse tails or fibres." See his Island of Bali (New York: Knopf, 1956), p. 356.

${ }^{62}$ The singa was traditionally a mythical beast. The word is usually translated today as lion; but the animal has never been found on Java.

63Translation from Pigeaud, Java in the Fourteenth Century, III, p. 123.

${ }^{64}$ Ibid., III, p. 108, Canto 91, stanza 3. It so happens that the highest musical mode in sléndro--siéndro pațet manyura--is named after that "carolling" bird, the peacock. 
ceremonies held to deify a Queen (the Răjapatni) in 1362: "On the singhãsana (lion-throne), splendid, high, superhuman was/Her place to be saluted."65

Java has her share of tigers, especially in the great Lodaya forest 66 near Ponorogo, where a sacred gong (bendé) called $\mathrm{Ki}$ Bradah, guardian of tigers, has traditionally been worshipped.67 The people there believe in a variety of tigers, including white tigers said to be ridden by kings in the past, invisible tiger spirits, buffalo (maésa) tigers and were-tigers (men who can turn into tigers). A local story (dongèng) ${ }^{68}$ about the first man ever to become a were-tiger includes reference to a white tiger called Barong-séta, thus providing a link between the tiger and the Barong mask. The ability to put on a mask or change one's appearance, and thereby become a were-tiger, enabled one to meet animal and demonic thieves on their home ground and defeat them. 69

Possibly the parade of the Barong with the whole reyog troupe (réyog kliling) bears some relation not only to circumcision and other processions but also to the traditional procession around the boundaries of a village on the occasion of the bersin desa (cleansing of a village). 70 Sometimes ritual wayang performances and tayuban parties accompany the ritual feasts (stametan) and other rituals, in order to cleanse the village area of dangerous spirits. In Bali, the Barong is still used in pesucian (village purification processions). The bersih désa in Java sometimes involves offering food to the spirit of the founder of the village, 71 thus linking the ancient custom to ancestor worship. But the whole ritual is dying out in Java, partly, it is said, because of poverty. It is also, no doubt, because of the lessening of village autonomy and the growing emphasis on secular national celebrations, rather than village rituals. 72

65Ibid., III, p. 75, Canto 65, stanza 1.

${ }^{66}$ Canto 61 , stanza 3 of the Năgara-Kĕrtāgama reports royal visits to Loḍay in 1357 and 1361. See ibid., IV, p. 164.

67The gong is said to have once saved its nobleman-owner's life by calling all the tigers in the wood to protect him; see Pigeaud, Volksvertoningen, p. 496.

${ }^{68} \mathrm{The}$ story, based on $\mathrm{R}$. $\mathrm{Ng}$. Soeradipoera's account published in 1921, is recounted in ibid., p. 432. The wise prince Prabu Jayabaya called a village watchman (umbul) to the court so that he could look after the prince's mount, the caged white tiger Barong-séta, which was blessed with superhuman knowledge. As the umbul was worried about the security of his village in his absence, the white tiger taught him a charm which could turn him into a tiger and back again into a human being. By using this charm, he solved the problem of thieves at home.

But eventually the umbul allowed the knowledge of the charm to spread. It was misused by people with bad intent. In punishment, the prince put the white tiger in his cage in the Lodaya woods and told the umbul, who should have kept the charm to himself, that he and his kin must look after the white tiger forever.

${ }^{69} \mathrm{Ibid}$., p. 433. Reference is made in Van der Tuuk's dictionary to white tigers under borong, a word mentioned in an Indian Cantri text (ibid., p. 432).

${ }^{\circ} \mathrm{I}$ am indebted for this suggestion to B. R. $0^{\prime} \mathrm{G}$. Anderson, who witnessed such a procession.

${ }^{71}$ See Geertz, The Religion of Java, p. 82.

${ }^{72}$ This is pointed out in C. Geertz, "The Javanese Village," in G. W. Skinner 
At some time in the past, a legend was attached to the old reyog dances. The legend is not an essential, integral part of reyog since, unlike a wayang wong plot, it does not provide a performance with a dramatic base, except in a very loose way. Like all folk tales, the legend appears in a variety of forms and has been subject to continual change. Staugaard's account, ${ }^{73}$ written in 1919 , may be summarized as follows:

The King of Bantarangin, whose name was Klono-Sewan-Dono, traveled to Kediri to ask for the hand of the princess in marriage. He was accompanied by 144 knights, under the command of Boedjangganong. In the jungle, the tiger--Rodjowono (King of the Woods)--tried to devour the horses. Boedjangganong fought the tiger, but failed to defeat him. The king himself appeared and asked the help of the hermit Kjai Goenoreso, who lived on a mountain nearby. After the hermit had managed to render the tiger harmless, the king gave a grand feast, graced by gamelan music and dancing, including a tandak dance by a woman with the name of Wajang Djopré and the clown Potrodjojo.

In the first scene of the performance described by Staugaard, four jaran kepang boys appeared riding painted horses, together with the king (K1ana), wearing a mask and a scarf; "the tiger" (Rajanawa or Rajawana), wearing a headpiece of peacock feathers, a tiger head and a be11 carried by two people under an enormous sackcloth, and Pentu1, a clown wearing a black mask. In the second scene, the masked Boedjang Ganong danced with the tiger in a mock battle, but did not defeat him. In the third, the old hermit Goenoreso, wearing a brown mask and white hair, managed to defeat the tiger. In the fourth, a feast was held at which the king received honors from the hermit and entertainment was offered to all present.

Pigeaud writes that according to the Regent of Blora the legend is an episode of the Panji story. According to this version, clown messengers carrying a marriage proposal to Kediri happen to meet the Barong, called Gembongwijaya, who is eventualiy defeated with the help of Jakalodra and Raden Panji Ino Kertapati's dog Bondet. 74 In a Ponorogo-style Barong/horse dance in Banyuwangi, the characters included a Panji, a Klana, two Singa Barong, four horse dancers, and the clowns Tembem and Pențul.75 In other cases, however, the Panji element is missing, as in a performance in Surakarta which included a Pujangganom (Bujangganong) or Jakalodra, a Singa Barong, and a Badut.76

(ed.), Local, Ethnic and National Loyalties in Village Indonesia (New Haven: Yale University Southeast Asia Studies, 1959), p. 38.

73"Koeda-Képang," pp. 421-22. Staugaard's account is based on P. W. van der Broek's, entitled "De Geschiedenis van het Rijk Kediri"; but even that differed somewhat, he writes, from the version he heard from participants he met through a local assistant wedana.

${ }^{74}$ Volksvertoningen, pp. 195-96. Other amusing characters in this performance included Temben or Semar, Untup, Pențul, Belot (wearing a bigger mask than Pențul's), an old man called Pak Gențung, and an old lady, played by a man, called Bok Brog.

75Ibid., pp. 190-91.

76Ibid., pp. 191-92. In Volksvertoningen, mention is also made of réyog 
A much more detailed account of the legend than Staugaard's is told in present-day Ponorogo, as follows. 77

A young king by the name of Sang Prabu Sri Klana ${ }^{78}$ Séwandana reigned long ago over the kingdom of Bantarangin. ${ }^{79}$ In order to increase his wisdom and power, he studied the science of the supernatural in the shrine (padépokan) of the hermit-sage (resi) Ki Ajar Lawu, also called Kyahi Gunoreso.80 The king was a favorite pupil of the kyahi. While studying, the king befriended a fellow pupil whose name was Radèn Pujangga Anom, heir to the throne of the rival kingdom of Kediri.

After long periods of meditation and observance of the example and teachings of the kyahi, the two pupils reached a degree of spiritual power, whereupon they were each presented with a valuable gift by the kyahi. The king was given a powerful whip called Jimat Samandiman. ${ }^{81}$ When struck, it sounded like the voices of a thousand thunderstorms. Prince Pujangga Anom was given an incantation called Welut Putih ("White Ee1").

One night, the king fell in love with a beautiful princess who appeared to him in a dream. She was the princess of Kediri and the sister of Pujangga Anom. When the king told his friend that he wished to marry her, Pujangga Anom supported the idea, partly because he was a friend and partly because he saw the political advantage of a match between the two kingdoms.

As was the custom, the king initiated proceedings by sending an official delegation to ask the princess' father, the king of Keḍiri, for her hand. Pujangga Anom agreed to head the mission as prime minister. Not wanting to be recognized by his father the king of Kediri, he wore the mask of a red-faced dwarf and changed his name to Bujang Anung.

It so happened that the arrival of Bujang Anung and his delegation in the kingdom of Kediri coincided with a military attack by the army of

performances in Ponorogo (pp. $185 \mathrm{ff.}$ ), Keḍiri (pp. 194-95), Bagelèn (p. 277), Madiun, Maospati, Magetan, and Ngawi (p. 186), Blora (pp. 195-97), Tulungagung and Kediri

(pp. 198-99).

${ }^{77}$ This version of the story is based on several similar accounts by réyog participants in the villages of Mangkujayan and Penitèn in Ponorogo, immigrants (of about four decades) from Ponorogo in Parit Lapis (Sri Medan, Johore, Malaysia) and a pamphlet by Andjar Any, entitled Keradjinan Réyog Suromenggolo (Ponorogo: 'n.p., 1969), pp. $5-8$.

${ }^{78} \mathrm{Kel}$ ana, or Klana, probably means "knight-errant," according to A. J. ResinkWilkens, "De Klana-dans," Djowà, III (1923), p. 99. In some versions of the legend, the king is called Radèn Bagus, according to Any, Keradjinan, pp. 5-8.

79 Bantarangin means "above the wind," that is, "lands north of the equator," according to Radèn Ngabei Poerbatjaraka, an informant of Staugaard "Koeda-képang," p. 421). This kingdom is sometimes referred to as Wengker-Radja, according to Any, Keradjinan, p. 5.

${ }^{80}$ The name Kyai Gunoreso is based on Kyai Guna Reksa meaning "Protector of Virtue." Staugaard, "Koeda-képang," p. 422.

${ }^{81}$ The long whip-belt of the "Wild Man" is classically associated with the warok and is a sign of his magical potency, according to a personal communication from B. R. O'G. Anderson. During the Maulud festival, "Ancient fertility rites: cracking of whips, are occasionally practised." Pigeaud, Java in the Fourteenth Century, IV, p. 209 . 
the "Dense Forest" (Alas Roban), which had advanced from the jungles to the northwest. Its strength lay ultimately in the magic power of its great leader, the Singa Barong.

The dwarf realized that his father's army was fast losing courage, so he took command himself and destroyed a large part of the Alas Roban army. The Kediri side was overjoyed but did not realize that the masked stranger who had saved them was really their own prince.

Bujang Anung then presented himself, still in disguise, to his father, who gladly accepted him as the leader of the delegation from the King of Bantarangin to seek his daughter's hand in marriage. He said he was very grateful to Bujang Anung for the defeat of the enemy but that the Singa Barong still tormented the people. Before he could agree to the proposed marriage, the Singa Barong himself must therefore be slain.

In order to accomplish this task, the dwarf pitted the strength of 144 of his cavalry against the side of the singa Barong. But all except four of the men and all their horses were eaten by the Barong, and the remaining men fled back to Bantarangin.

King Séwandana decided it was time to enter the scene himself. He ordered each of his soldiers to wear magic belts and to attack again with all their might. They succeeded in defeating the enemy.

A duel was then fought between the king and the Singa Barong, whose magic power made him invisible. The king decided it was time to use his magic whip, and this brought him victory.

But one more condition had to be fulfilled before the wedding could take place. The princess had asked for an underground tunnel to be built connecting Keḍiri and Gunung Kelud. With the help of Pujangga Anom's White Eel incantation, it was built in one night, and the marriage conditions were at last fulfilled.

Now Pujangga Anom, by appearing masked before his father, had deceived him. To deceive a king was a serious crime, and Pujangga Anom was cursed by the gods. He was unable to remove the mask from his face; it seemed he would have to wear it forever. There was no denying, however, that he had been very daring and successful in his exploits. The gods therefore forgave him, and he was eventually empowered to take off the mask.

The King of Kediri was very happy on the occasion of his daughter's wedding, reunited as he was with his son from whom he had been separated for so long. But the princess' happiness gradually disappeared as the months passed and she was unable to bear a child. She was kedi (barren), the word from which the town Kediri is supposed to have derived its name. ${ }^{82}$ Her husband desired a child very much. Believing that she could only free her husband from childlessness by her own death, she killed herself. Her husband was so distressed by her death and the misfortune it might bring that he lost the ability to rule his people.

Pujangga Anom tried to find a cure for his depression. Eventually, the idea of a réyog performance came to him, based on the story of

82Ponorogo immigrants in Parit Lapis, Johore, say that the princess was neither a man nor a woman (banci) and was therefore barren. Pigeaud thinks that Kediri probably means "to stand," referring to phallism (Java in the Fourteenth Century, IV, p. 46). 
the king's victory over the Singa Barong. At last a way had been found to raise the spirit of the king. Whenever he felt downcast about the loss of his wife, he watched réyog pageants in which he saw himself, a clown or two, Pujangga Anom, the cavalry, and the Singa Barong, accompanied by loud, stirring music on the gamelan réyog.

Staugaard's account of the legend establishes that it was attached to réyog at least as long ago as the early twentieth century. Some aspects might suggest that it is of great age, for example, the claim that the ancient town of Kediri was named after the barren (kedi) princess of the legend. But these (dubious) touches do not prove that the legend as a whole, and in particular its use in réyog, are very old. For one thing, the legend is not an essential element of a reyog performance. For another, it substitutes "historical" for ancient religious meaning. And it has a highly aristocratic quality, in contrast to réyog's basically peasant character.

While reyog glorifies the Barong, the legend lays the emphasis on such aristocratic concepts as political marriage, the crime of deceiving a king and the diminishing of royal power and prestige by the inability to procreate. To top it all, the legend indicates that the primarily abangan art form of réyog was royally conceived in the court for royal consumption. This is an excellent example of what one suspects was a relatively frequent turning of the tables, with the courts claiming to have invented art forms and techniques that were really borrowed from the rural areas, as for example the kendang rhythms called ciblon and koțekan (rice-pounding in interlocking rhythms by village women), and the practice of masked dancing. In many cases, the really creative role of the courts lay in their refining, elaborating, intellectualizing, and adapting of selected artistic ideas which originated in rural areas for courtly requirements and taste. This is not to deny, of course, that original ideas were also produced by the priyayi and abangan artists who worked in the courts.

The legend ingeniously explains some aspects of réyog performance, for example, the coarse appearance and rough behavior of Pujangganom. But it is inadequate in its explanation of the kasar character of Klana Séwandana who is said to be an ancestral king of the Ponorogo people. The legend does not, in fact, portray him as a coarse figure, but respectfully emphasizes such alus qualities as the spiritual power he attained through the art of meditation and his gentle sadness and introverted lethargy after the suicide of his wife. In réyog performances, on the other hand, the king is presented in an ironic and subtly anti-priyayi light. He is depicted as a rough, coarse Klana, someone who does not even have the distinction of being a Javanese. He is really only an uninitiated foreigner, a person who has not yet learned what it means to be a Javanese.

To some extent the deep-seated antagonisms in the past between lord and peasant found artistic expression in the distinction between alus and kasar. Réyog participants, far from apologizing for their primarily non-alus art form, delight in its kasar earthiness. This is most clearly exemplified in the unsophisticated dance movements, the lack of emphasis on plot and the "unrestrained" kasar music, all of which contrast strongly with courtly values, with their strong emphasis on social status, their genteelness, their smooth controlled ele- 
gance and sophistication. Alus-ness is indubitably associated with being high-born, whereas kasar-ness is regarded as being the "natural" state of the low-born. Participants in réyog deliberately perform in a more kasar way than they normally would on other occasions. For example, in different circumstances they may dance quite alus dances or play alus music. It is not that they are unable to perform in an alus way in réyog (although that is sometimes the case); it is primarily that they do not want to, that to do so would be inappropriate. ${ }^{83}$

This element of anti-priyayi and antiestablishment protest in réyog performance is apparently both artistic and political. As a result of the "powerful, latently contradictory elements of allegiance and alienation" between the peasants and the ruling elite, who preferred their own courtly and/or foreign art and institutions, peasant communities "stubbornly retained their own identity, which was bound up with attachment to the soil and to age-old village cults," 84 including the old reyog dances.

In fact, the aristocratically oriented legend may have been attached to and promoted in réyog by religious leaders such as the kyahi in the service of dissident noblemen, in an attempt to gain peasant allegiance. Holy (kramat) men ". . . frequently revived and gave contemporary application to ancient legends. . . "85 In addition, "deeprooted millennial beliefs have long been used by counter-elites for agitation and insurrection against the established wielders of power, particularly at the local level."86 we know that kyahi, mentioned in the reyog legend and in the Serat Cabolang (the gemblak-like hero of which was the son of a kyahi), even allowed réyog-type art forms to be associated with the pesantren. They also stirred up peasant antagonisms against the priyayi and the Dutch by manipulating ancient rituals, nativist feelings, and millenarian beliefs. Kyahi have "always been regarded with suspicion by government authorities, who see their ability to mobilize mass support as a potential danger to the regime."18

Réyog has demonstrated a latently and sometimes overtly antagonistic relationship to the authorities throughout this century. The Dutch colonial government, supported by religious leaders (penghulu) in the mosques, tried to suppress such popular activities as contests, betting, and cock-fighting, because they were seen as potential disturbances of the peace and a waste of money. Réyog too was seen as a dangerous, subversive art form, partly because it was associated with "troublemakers" (warok); two adjoining villages were not allowed to have réyog

${ }^{83}$ Not all Javanese try to cultivate an alus personality, the most famous recent example of this being Sukarno who, despite having absorbed the traditions and alus" qualities of wayang (and, assumably, réyog too, in his grandparent's home in Tulungagung), admired the bold, blunt, rough Bima in preference to the alus Arjuna. A projected image of vigor and earthiness in social behavior, as in Sukarno's case, is not necessarily less admirable than the image of an arch-refined, gentle person, who can in some cases be quite weak and impractical. Especially in the rural areas, where the great majority of Javanese live, there is a place for both character types, just as there is a place for both gamelan klenèngan (music for contemplative listening) on the one hand and gamelan réyog on the other.

${ }^{84}$ Sartono Kartodirdjo, "Agrarian Radicalism," pp. 81 and 86.

$$
{ }^{85} \text { Ibid., p. } 81 . \quad 86 \text { Ibid., p. } 75 . \quad 87 \text { Ibid., p. } 78 .
$$


on at the same time for fear of provoking clashes.88 The réyog legend may in fact, have been seen by the colonial authorities and Indonesian modernists as a useful alternative explanation to the ancient religious one, thus conveniently glossing over its "primitive" and embarrassing sexual and political elements. The legend was possibly regarded as a peaceful substitute for the subversive, erotic elements promoted by the warok.

The kucing-kucingan is apparently biased toward the aristocracy, too, glorifying the victorious Klana at the expense of the ancient Barong figure. Philosophically, it overemphasizes the significance of Klana's temporary victory. The scene is not mentioned in Pigeaud or Staugaard. One suspects that this final reyog is also final in the sense of being the most recent addition of all the scenes. Its inclusion in a performance is strictly optional. Its primary appeal, in any case, is simply that of entertaining acrobatics.

In the post-Independence era, reyog has been subject to considerable change. It has been manipulated by various political groups, used by the authorities to promote "modernization," and subjected to a degree of political repression. Small wonder that some of the old ritual and religious elements have partially been lost, the new type of associated political excitement and the increased emphasis on the entertainment elements of reyog shaping its changing meaning and the extramusical connotations of the music to its listeners.

The process of secularization and modernization had already advanced considerably during the latter part of the colonial period in the urban areas. The abangan villagers had largely rejected the effects of these trends when they occasionally impinged on their lives, nurturing the artistic and other expressions of their identity in selfdefense. But from the 1950s, the villages also began to be influenced by measures taken by the state to modernize village society, through a rural development (pembangunan desa) section of the Ministry of the Interior. These moves were reflected among other things in the content of the dor of réyog and in the texts and styles of new gamelan-accompanied songs.

In fact, a secularization of artistic attitudes had already begun in the 1920s, when Indonesian nationalists began to adapt some of the arts (especially Western-influenced art forms like the novel, diatonic songs, and painting) for political purposes, to popularize their eclectic Indonesian-Western ideas. It was not, then, a big step to take when in the 'fifties political parties such as the PNI and PKI began to present their ideas through cultural symbols of the past, adapting old art forms in order to reach the peasants and other sections of the community.

In the Sukarno period, réyog was used quite extensively by rival political parties to promote their policies. Certain villages were known for their "Réyog PNI," with the name of their party and village painted boldly on the Barong mask and the dor chanting such things as "P-N-I" and "Bantèng wulung" ("blue-black bull," symbol of the PNI).

${ }^{88}$ This is according to a communication from B. R. O'G. Anderson. 
Other villages were known for their PKI or NU réyog groups, a1though not many affiliated themselves with the latter. The custom of paid performances (réyog mbarangan) in street shows, at weddings, and other celebrations partly gave way to performances without financial reward, as political reyog troupes traveled from village to village propagating the ideas and symbols of their political party sponsors. Intervillage and interparty rivalry among political réyog troupes was high, a factor which seems to have increased the emphasis on the virtuoso dor and acrobatic elements and the glory of the pageantry, for example, by making bigger and better Barong, thickly covered in peacock feathers imported specially from Kalimantan.

Warok-gemblak participation was still to be found in some performances, but it was deemphasized in others. Some PNI and PKI groups regarded the phenomenon as being out of keeping with modernization and social reform, while others thought it represented, like all the old religious elements, a kind of opiate of the people, sustaining nonrationa1, backward thinking. Counteracting the effect of these ideas, however, was a resurgence of nativist artistic thought, which was particularly strong in the early 1960 s and which regarded foreign culture in Indonesia as decadent and polluting. Politico-cultural groups adapted Indonesian art forms to suit their activities, and promoted their particular styles of performance. Réyog groups in Ponorogo and elsewhere multiplied. Over three hundred villages in Ponorogo had réyog sets before and during 1965, the year when communism and the expression of left-wing thought were outlawed in Indonesia.

Réyog is still one of the most popular art forms in Ponorogo. Almost every village in the area can claim to have, or to have had at some time, a réyog set. But many have given them up for political reasons. According to an Art Survey carried out by the office of the Bupati (district head) of Ponorogo in 1971, only 61 groups of reyog performers were registered, comprising 1,206 members, though about 150 villages still owned réyog sets. Each registered group had the name of its respective village painted on the Barong head for identification (as in Plate 3 above). Unlike the situation before 1965, a larger number of kețoprak than réyog groups were registered, namely 96 groups with 3,814 members. There were also 23 wayang wong groups with 903 members, 10 ludruk groups with 360 members, 1 sandiwara (modern theater) group with 25 members, and 50 karawitan (gamelan-playing) groups with 507 members. The PNI's art organization, LKN (Lembaga Kebudayaan Nasiona1), stil1 comprised reyog, ludruk, and other subgroups, the réyog subgroup being called Bren (Barisan Réyog Nasional--Nationalist Reyog Front). Lesbumi, the art organization of the Nahdatul Ulama party, also had a réyog subgroup called Tjakra.89 Communist réyog groups were banned from 1965, when many artists disappeared or were arrested.

Emphasis is not put on the warok-gemblak phenomenon in Ponorogo's official descriptions of réyog today. The rebellious warok tradition would not, in any case, be commensurate with the present-day official concept of 1 aw and order. The emphasis in the kabupatèn (district) office is now placed on the legend. Gemblak are banned by local

89Most of the information in this paragraph was supplied by the Bupati of Ponorogo, Komisaris Polisi Sudono Sukirdjo. 
governments in some parts of East Java partly, it is said, due to santri disapproval, and partly to prevent gemblak from being fought over, thus disturbing the peace.

In the period leading up to the general elections in 1971 , reyog was used most extensively, indeed almost exclusively, by Golkar, which gained 62 percent of the total Indonesian vote. A few PNI groups had their audiences chanting out the letters "PNI" en masse during réyog performances. But Golkar réyog groups dominated the scene, led by kabupaten organizers who worked through the village heads (Zurah), upon whom pressure was brought to bear to insure a large Golkar vote among the villagers.

Today, parties like the NU and PNI do not exist any more, subsumed as they were in 1972 under the umbrella of two large political federations. The Golkar reyog subgroups still formally exist, however. Réyog is sometimes used today in business exhibitions to advertise Ponorogo goods, as in the national sports week (Pekan olahraga Nasional VII) in Surabaya, July 1969. Local authorities have also begun to think of promoting réyog as a tourist attraction. Special troupes are sometimes organized to perform on national and cultural occasions, not only in East and Central Java but also in Jakarta. A relatively new form of réyog called Sendratari Singa Barong ("Barong dance-drama") is sometimes referred to as a "ballet," like the Ramayana Ballet (which performs Ramayana dances for tourists and others at Prambanan, Central Java). The Ponorogo "ballet" has on occasions even been performed in Surakarta, the city famous above all others for its classical tastes.

Ponorogo people still insist that their form of reyog has never been performed in trance, unlike réyog in areas like Madiun, where players enter a state of trance (dadi mabuk) and perform abnormal feats such as glass-eating with no apparent aftereffects. Staugaard's ${ }^{90}$ and Pigeaud's91 accounts of réyog Ponorogo support the claim that it is not traditionally associated with trance (kasurupan), unlike the Tulungagung, Madiun, and other varieties. The people of Ponorogo say that these other styles are not "pure," but are adulterated borrowings from the "original" réyog Ponorogo. Réyog as performed outside the Ponorogo area is, in fact, closely related to the trance drama which is elsewhere called jaran (or kuda) kepang, kuda lumping, or èbèg. In these forms, the warok-gemblak phenomenon is replaced by a focusing of attention on entranced performers, who believe they are in contact with spirits which have made them clairvoyant. Réyog Ponorogo has always emphasized eroticism and pageantry, symbolizing spiritual power rather than seeking it through trance inducement and spirit calling. Ponorogo inhabitants are right when they claim that the meaning and form of their réyog is unique in Java.

90See "Koeda-képang," p. 422.

${ }^{91}$ Volksvertoningen, p. 237. Pigeaud mentions trance performances in such places as Kediri and Tulungagung (ibid., p. 238). 


\section{Transcriptions}

The author acknowledges the inadequacy of Western staff notation for representing the intonational and rhythmic variability of Javanese music.

Signs used in the transcriptions

1. Kendang

Left-hand drum sounds:

$t=t a k$, a sharp rap with four fingers on the upper part of the drum skin, the thumb resting on the top of the drum, damped on the right-hand end.

0 = tong, a tap on the edge of the skin, without damping.

1 = ket, a tap with a right-hand finger on the center of the skin, without damping.

Right-hand drum sounds:

$\mathrm{b}=$ dah or dang, a very resonant undamped tap with fingers and palm on the center of the skin.

$\mathrm{p}=$ tung, a fairly resonant undamped tap with the fingers near the edge of the skin.

Combined right- and left-hand drum sounds:

$\mathrm{d} l=d$ lang, namely dang and tak played together, without damping.

pl = tzung, namely tung and Zung (a tap with a finger of the left hand) played together, without damping.

2. ' $\boldsymbol{p}=50$ cents or less lower than the pitch of the tone.

$(+)=50$ cents or less higher than the pitch of the tone.

3. 9 an abrupt break.

4. m vibrato of narrow amplitude.

5. $P p P$ slide anticipating or following a note.

6. Rhythm: $\quad \overline{d l}=\int_{d l}, \overline{t_{p} t}=\tilde{t p t}_{\boldsymbol{J}}, \cdot=$ rest. 
I. PAMBUKA

for Gamelan Réyog

(PAMBUKA continued)

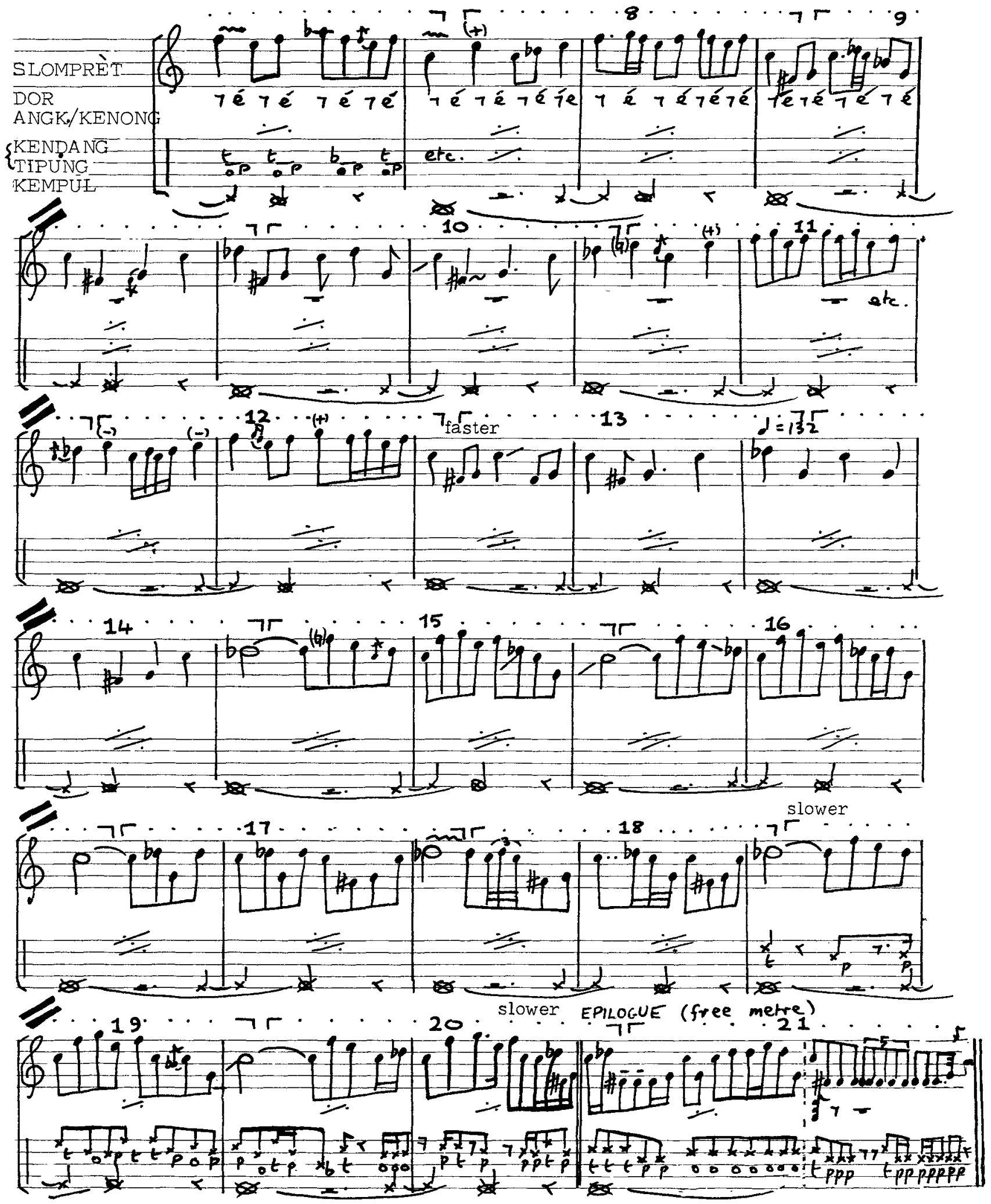


11 PONORAGAN

- excerpt from the beginning

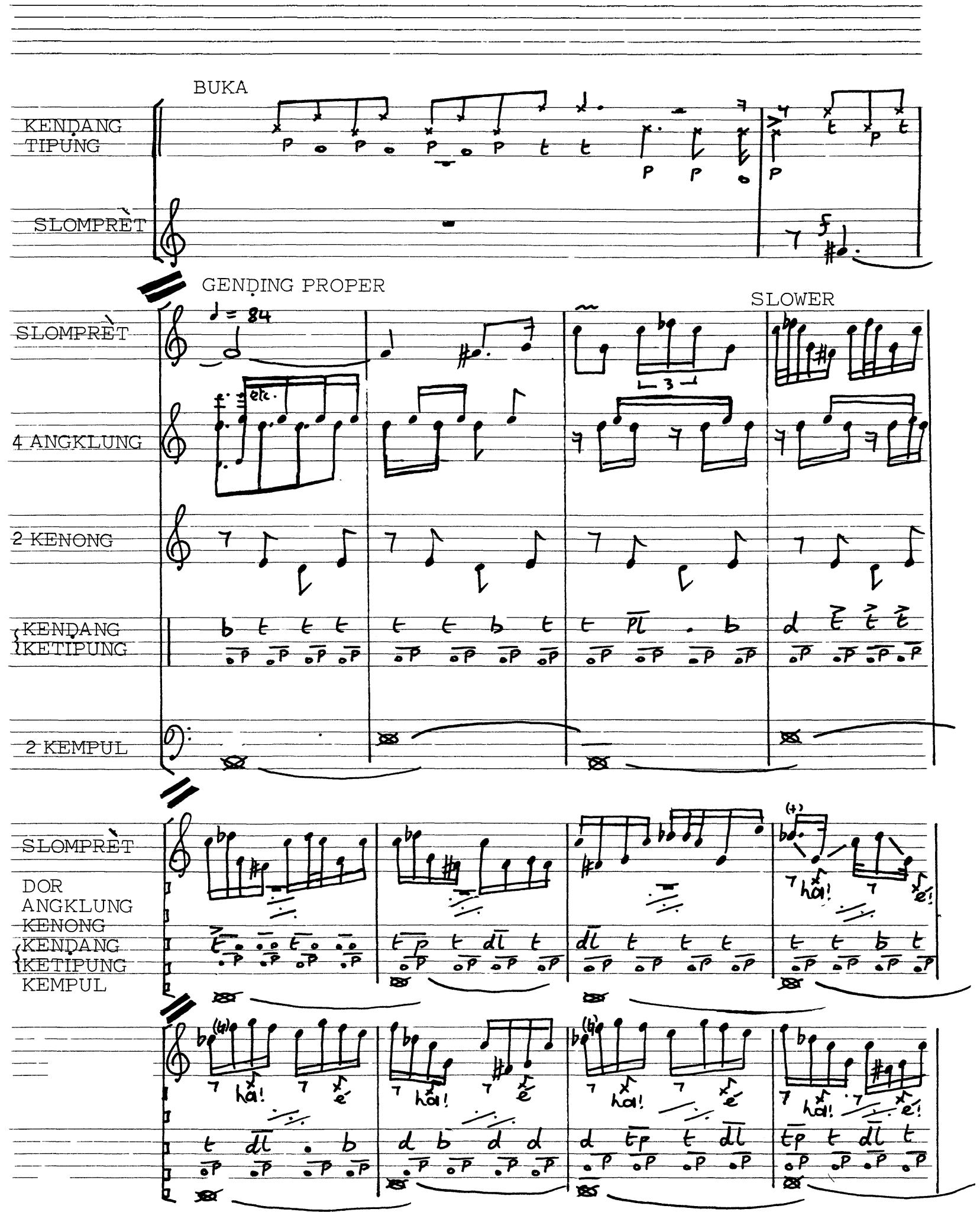




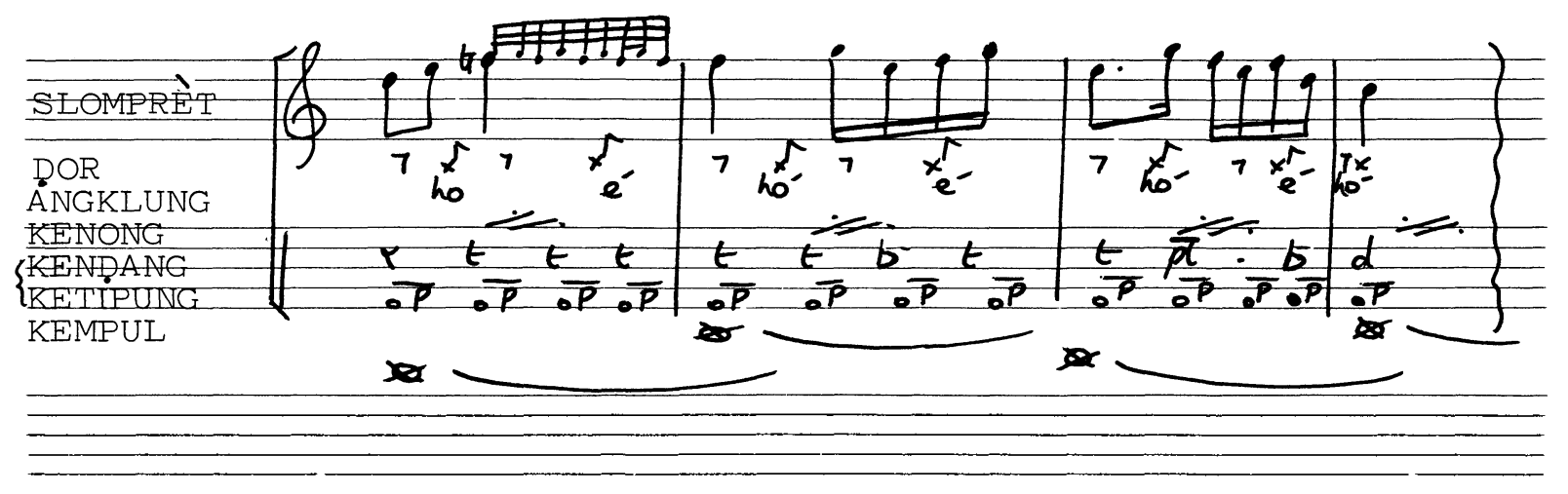

III SONTOLOYO
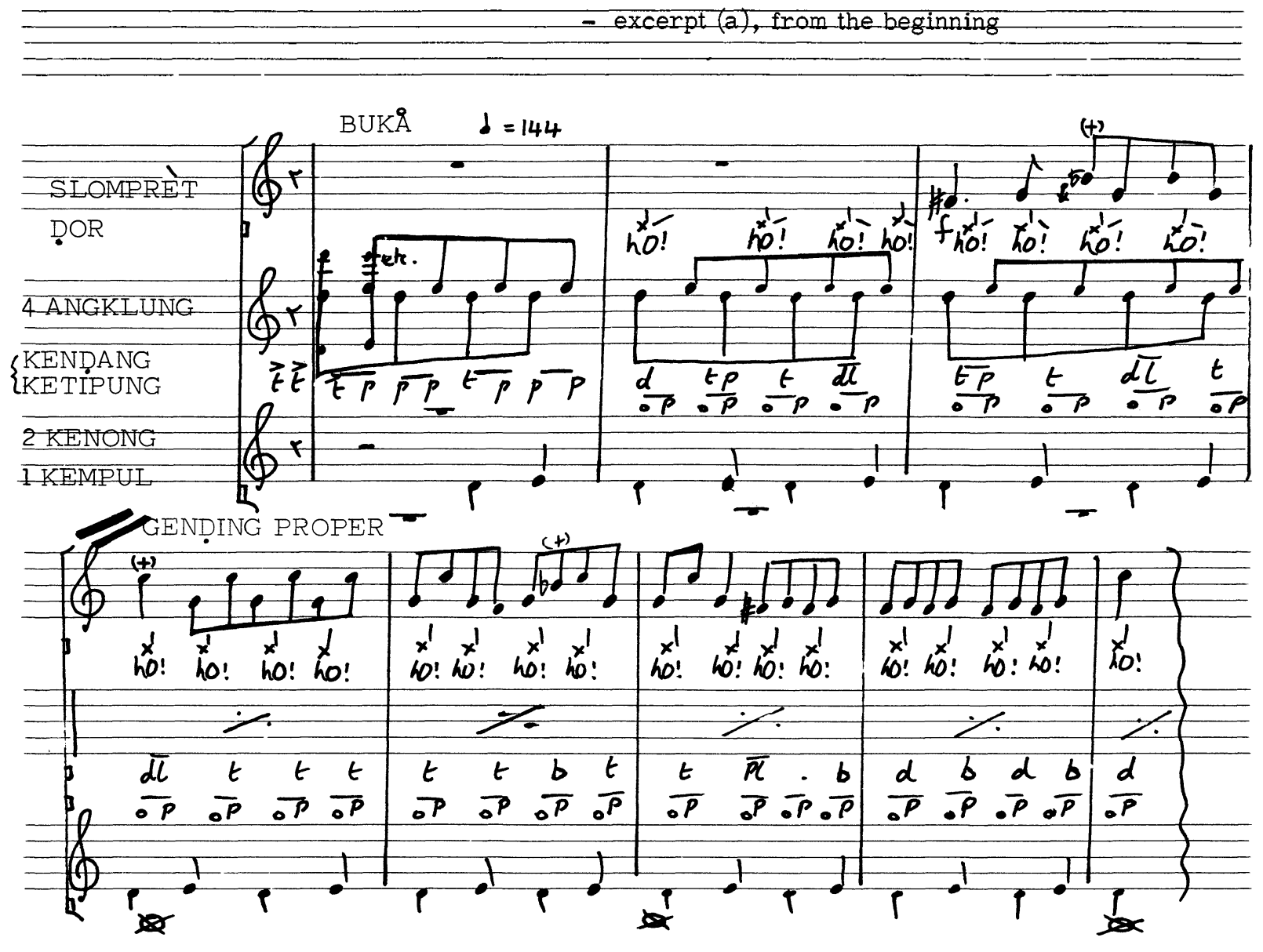

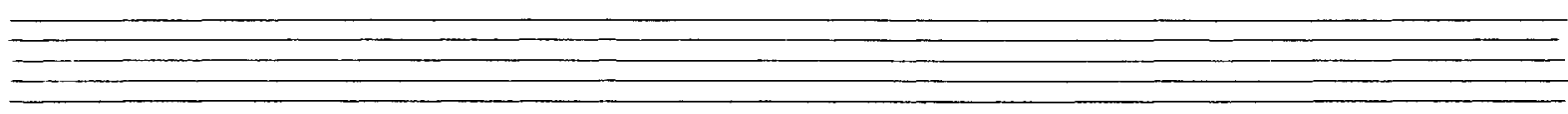


- excerpt (b), 7 strong kempul strokes after excerpt (a)

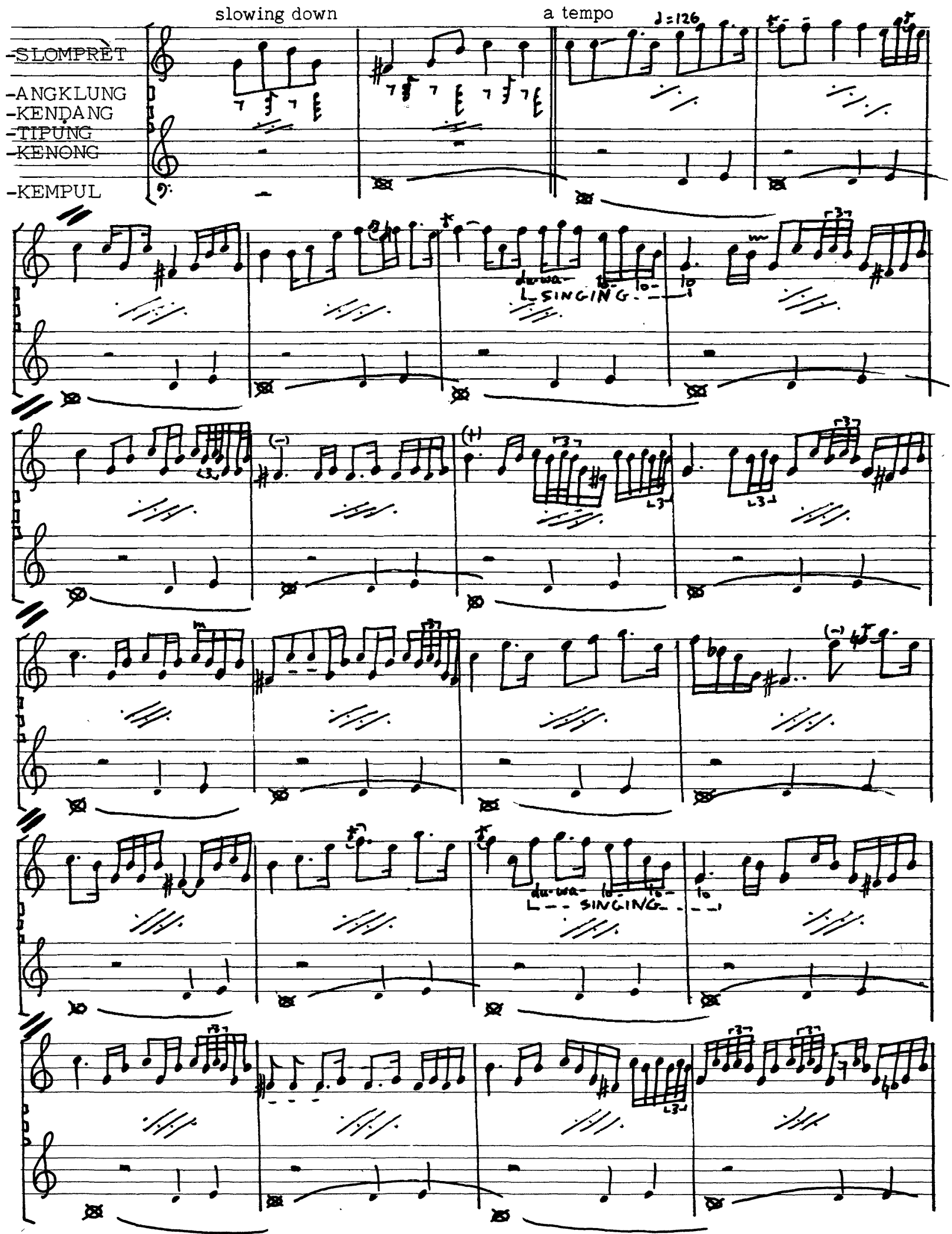

SINGING: participants sing a phrase doubling the Slomprèt line 
(SONTOLOYO - excerpt (b) continued)
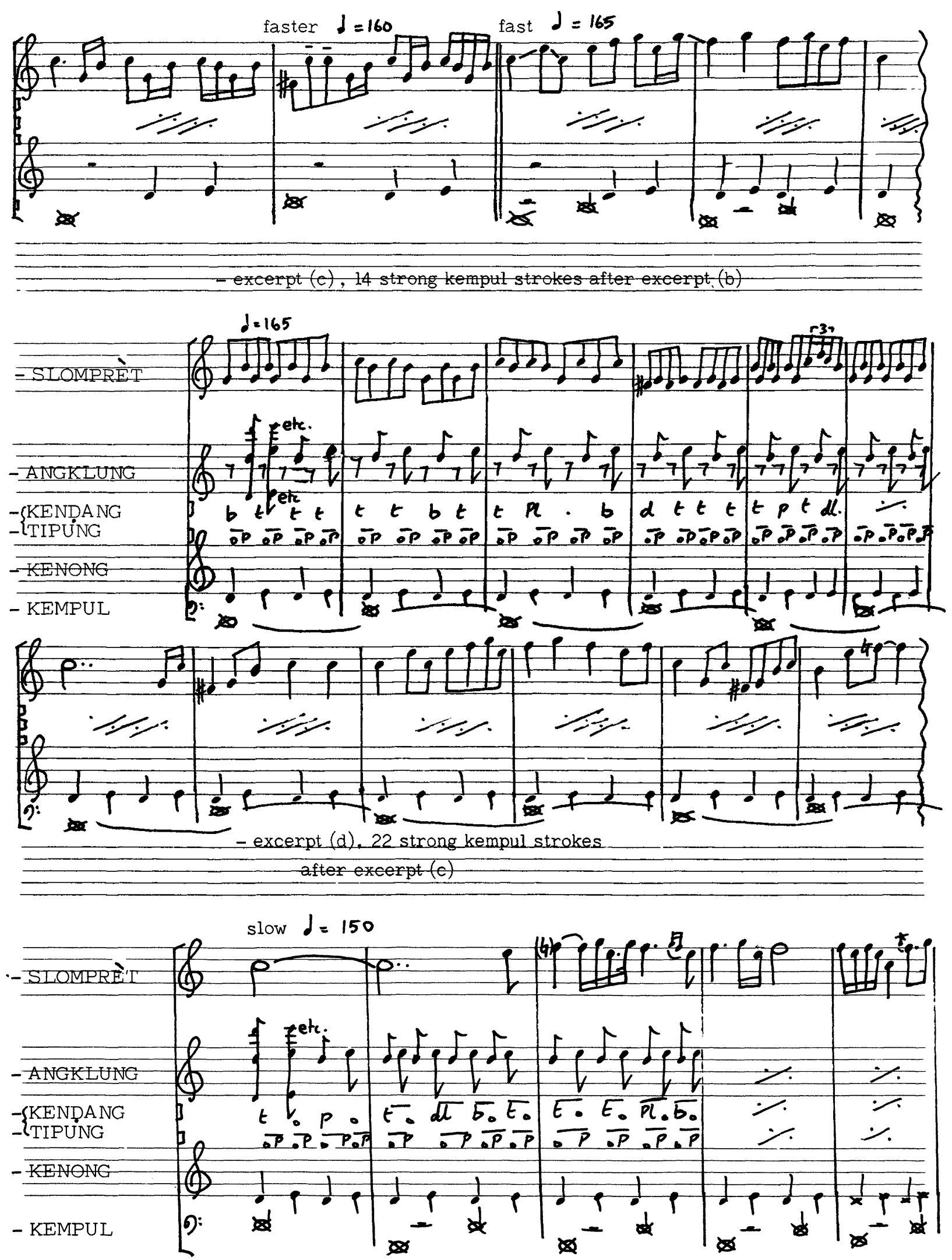
(SONTOLOYO - excerpt (d) continued)

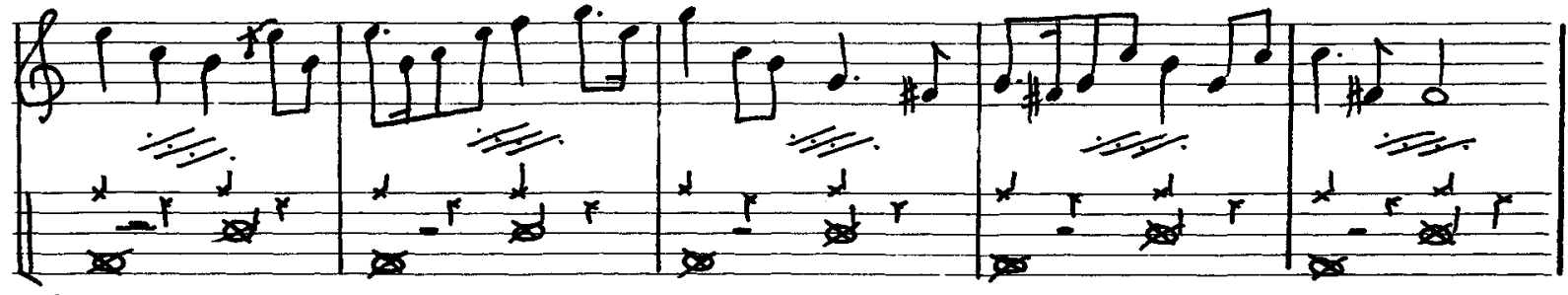

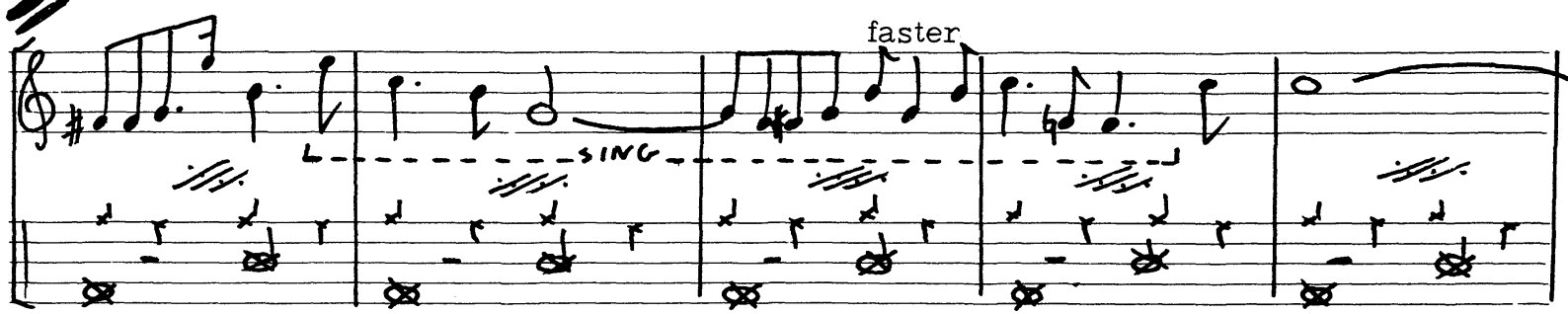

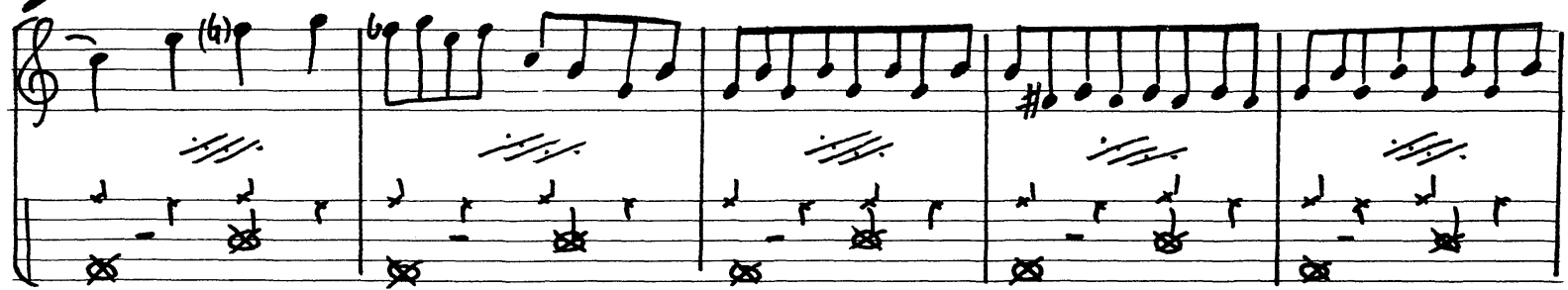

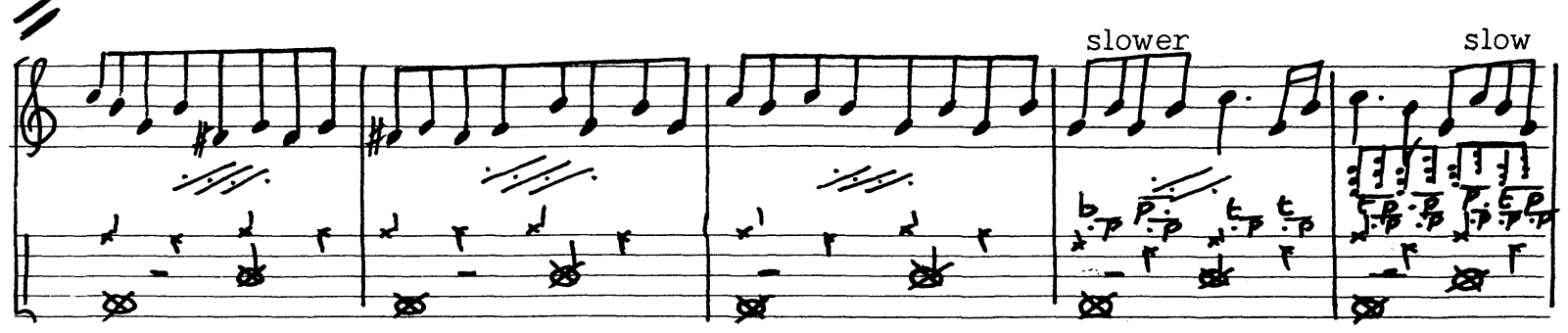

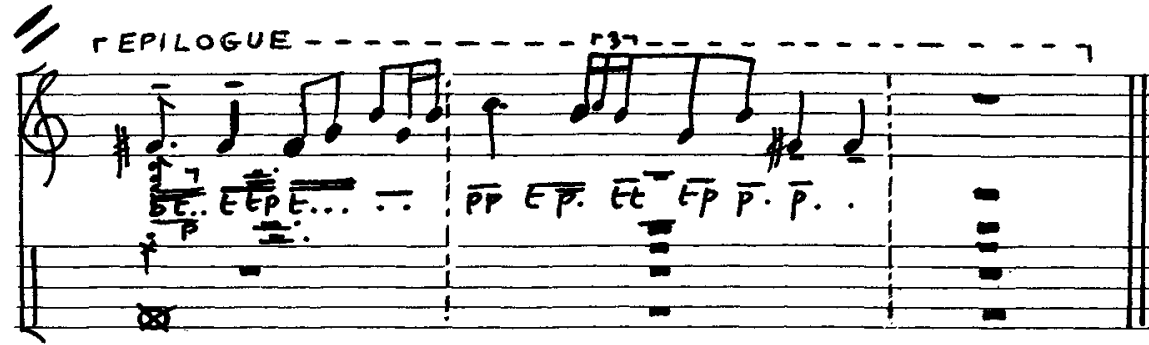


127

IV JARAN KE ́PANG - excerpt (a), near the beginning of the piece
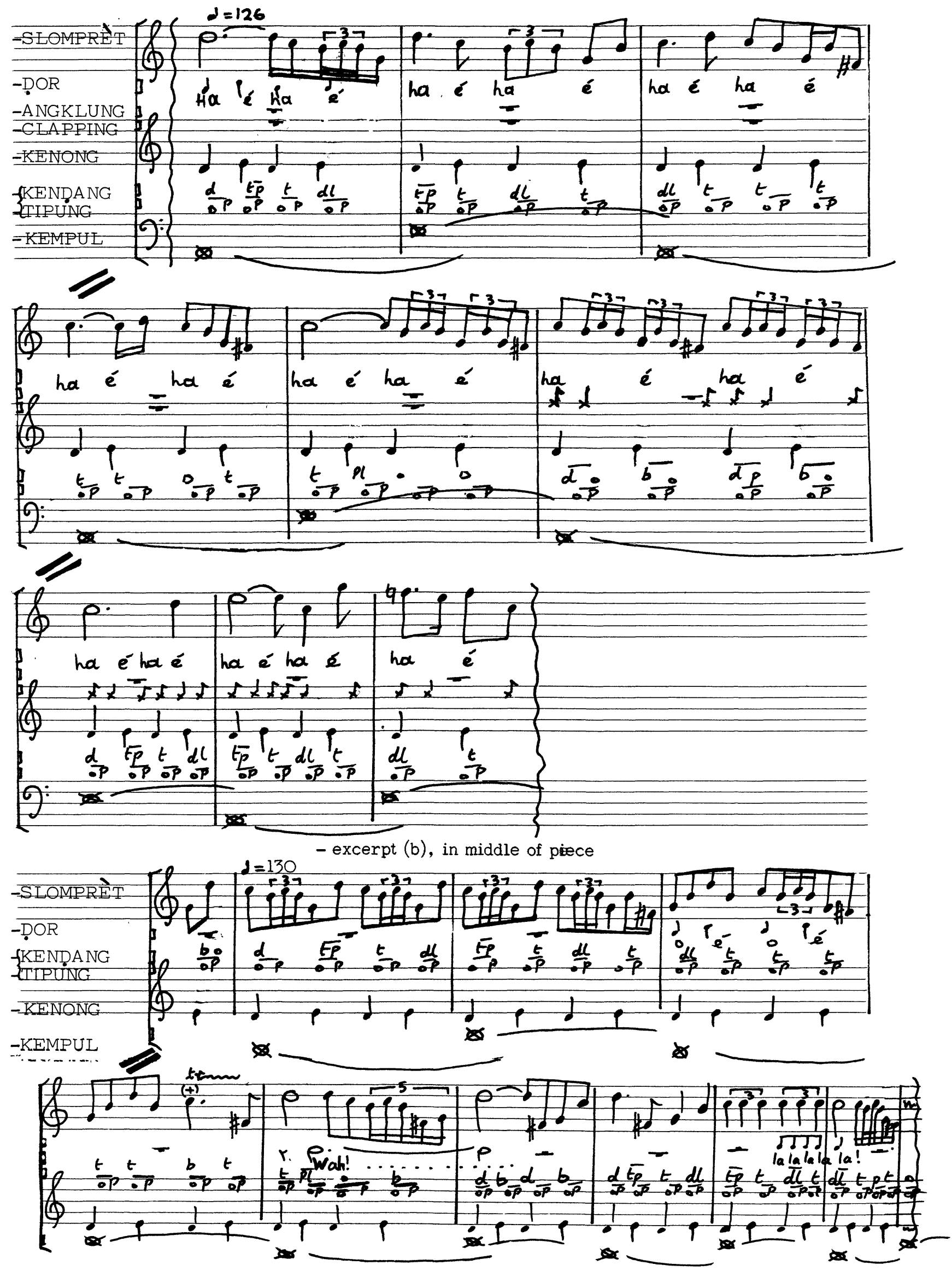
V PUJANGGANOM NYLAMUR DADI PENTUUL - excerpt (a), from the beginning of the piece

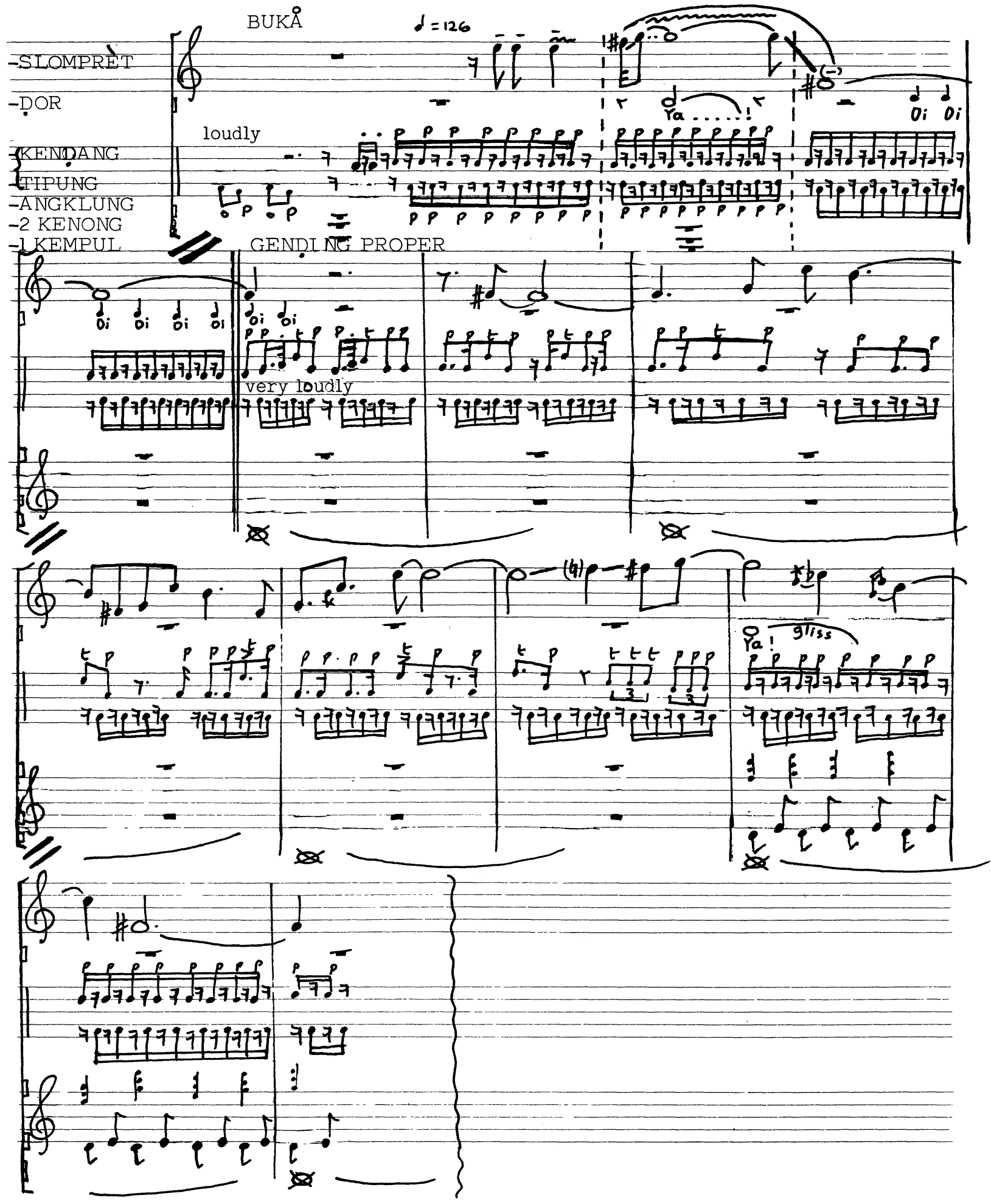


(PUJANGGA NOM continued)

- excerpt (b)
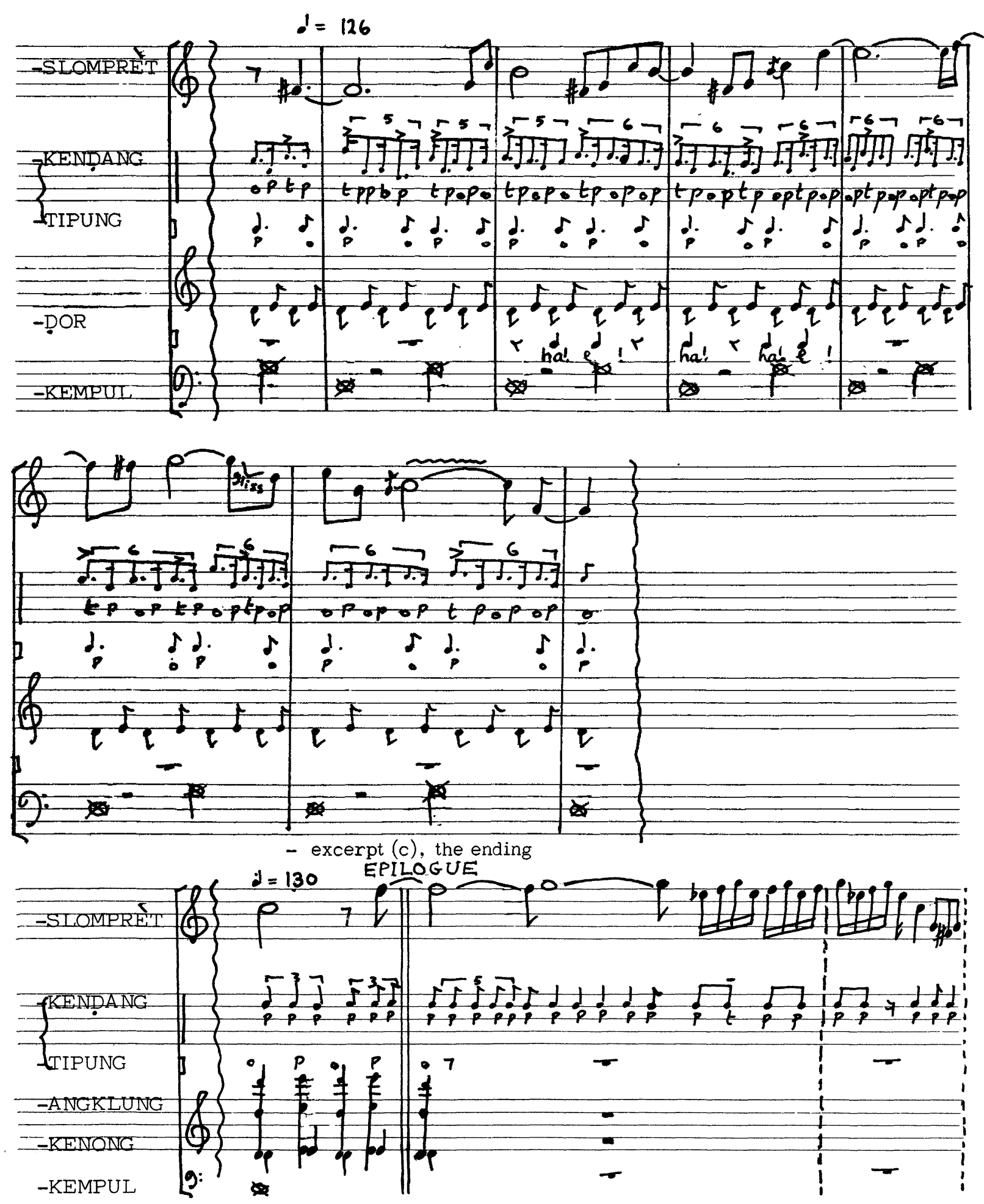
(PUJANGGANOM excerpt (c) continued)

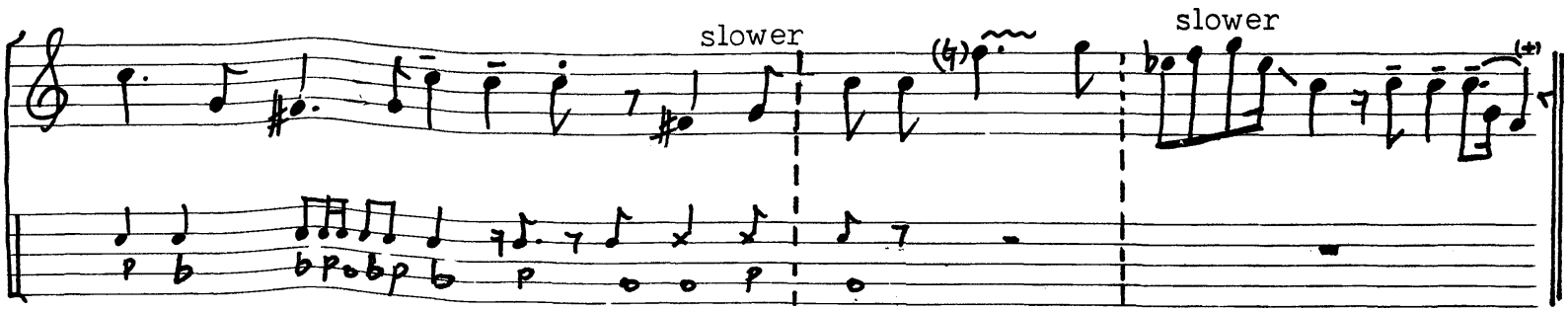

VI BARONGAN

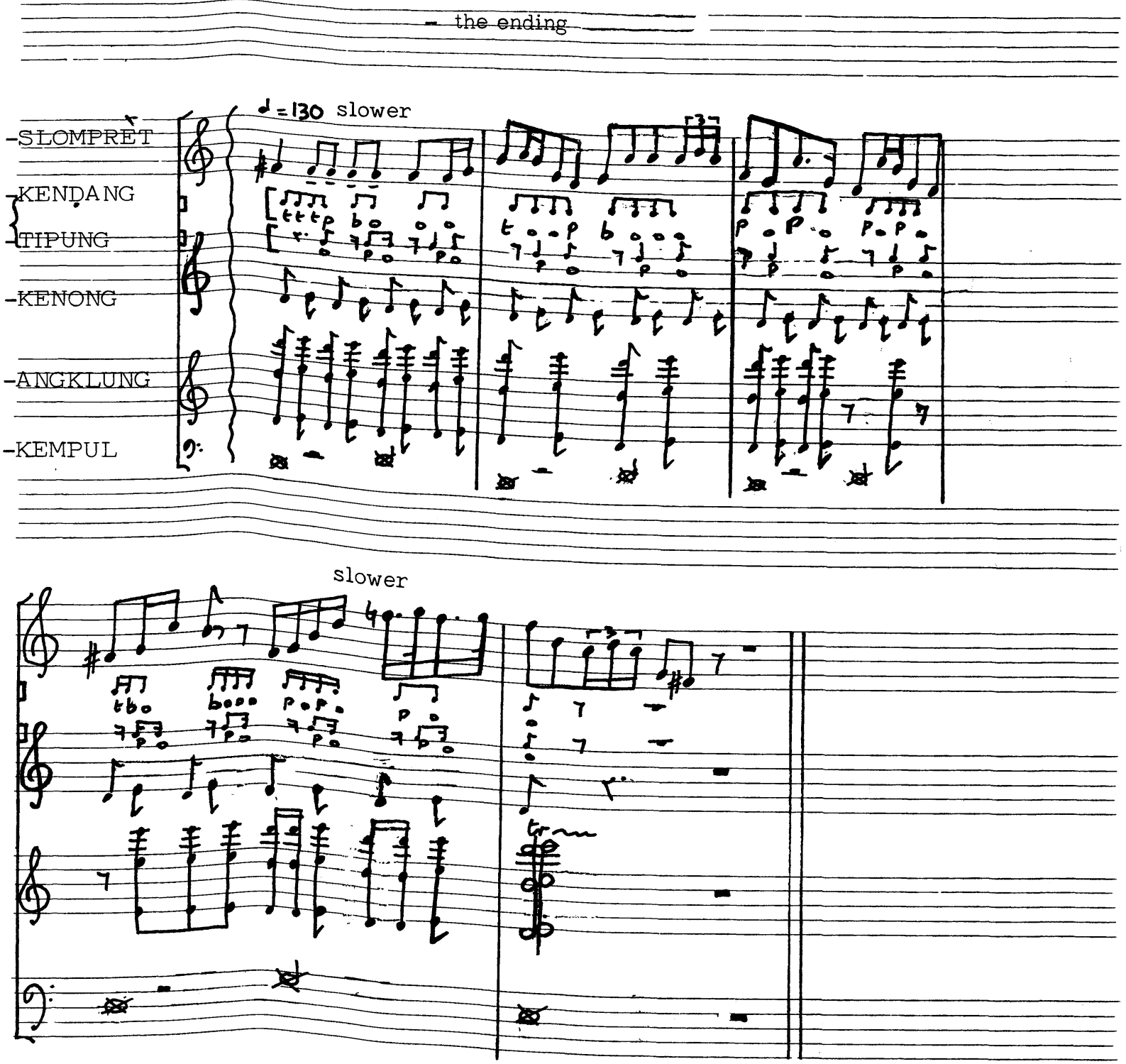

